Published in Current Diabetes Review, Volume 15, Issue 1, 2019 by Bentham Science.. The published manuscript is available at EurekaSelect via http://www.eurekaselect.com/openurl/content.php? genre $=$ article \&doi $=10.2174 / 1573399814666171227214845$

\title{
Patients' illness perceptions of type 2 diabetes: A scoping review
}

\author{
Elena D Dimova ${ }^{\mathrm{a}^{*}}$, Ashleigh Ward ${ }^{\mathrm{a}}$, Vivien Swanson ${ }^{\mathrm{b}}$, Josie MM Evans $^{\mathrm{a}}$ \\ ${ }^{*}$ Corresponding author \\ ${ }^{a}$ Faculty of Health Sciences and Sport, University of Stirling, FK9 4LA, Scotland \\ ${ }^{b}$ Faculty of Natural Sciences, University of Stirling, FK9 4LA, Scotland
}

\begin{abstract}
:
Background. People's personal perceptions, or illness representations, of type 2 diabetes can act as barriers to successful selfmanagement.

Introduction: Understanding patients' subjective perceptions of type 2 diabetes can aid the design of evidence-based care and appropriate educational programmes. This scoping review provides a narrative account of previous knowledge of patients' illness representations of type 2 diabetes.

Method: Quantitative and qualitative studies that explored patients' illness representations of type 2 diabetes, as defined by Leventhal's Common Sense Model, were included.

Results: Thirty four studies were identified for this review, but only 14 studies were carried out in a general population of people with diabetes. Illness representations varied across study populations. While it is clear that the perceptions of ethnic minorities and marginalised groups are embedded in their historical and cultural backgrounds, it is also important to understand the views of the wider population.

Conclusion: The review highlights the need for self-management interventions to reflect the target population's representations of type 2 diabetes in order to inform interventions and clinical practice.
\end{abstract}

Keywords: type 2 diabetes, illness representations, patients, self-management, scoping review

\section{INTRODUCTION}

Non-adherence to lifestyle regimens and medication in type 2 diabetes can lead to a wide range of complications, with repercussions for both the individual and the health system [1,2]. Despite, evidence-based guidelines [3, 4] to encourage appropriate self-management in order to prevent potential complications of type 2 diabetes, self-management remains relatively poor in people with the condition $[5,6]$. One potential way to explain poor diabetes self-management is through illness representations and the Common Sense Model [7]. According to the Common Sense model [7] people form their own representations of illness and these representations influence the way they respond to and cope with illness. Leventhal et al. [7] and Moss-Morris et al. [8] describe seven components of illness representations: identity (symptoms), consequences, timeline, cause, curability/controllability, emotional representation and illness coherence (Table 1). These personal representations of illness can act as barriers or facilitators to successful selfmanagement behaviours, such as diet and exercise regimen adherence, blood glucose monitoring and clinical attendance
$[7,9,10]$. For example, if patients believe they can control the course of their diabetes, they will be more likely to adhere to diabetes regimen that emphasises personal agency [10]. Understanding patients' subjective perceptions of illness can shed light into understanding their motivations to manage their type 2 diabetes. The current scoping review provides a detailed summary of previous research that has explored the illness representations of type 2 diabetes among people with the condition. The terms representations and perceptions are used interchangeably. The review results have implications for the design of evidence-based care and appropriate educational programmes for people with type 2 diabetes.

Insert Table 1 about here

\section{METHODS}

\subsection{A scoping review}

A scoping review is a technique used to "map" relevant literature in order to address broad topics where different 
study designs are applicable [11]. Scoping reviews are often undertaken to examine the extent and nature of research activity in a particular field, to determine the value of undertaking a full systematic review, to summarise and disseminate research findings and to identify research gaps in the literature [11]. Scoping reviews do not address issues of quality appraisal, so they have the potential to produce a large number of studies with different study designs and methodologies [11]. The review followed the framework provided by Arskey and O'Malley [11] and later refined by Levac et al. [12]. Its aim was to summarise evidence surrounding illness representations of type 2 diabetes.

\subsection{Search strategy}

The research question was: What is known from existing literature about the illness representations of type 2 diabetes among people with type 2 diabetes? We searched MEDLINE, PsychINFO, CINAHL, ASSIA and ProQuest, using the terms "illness perceptions", "illness representations", "attitude to health+", "attitude to illness+", "perceptions", "type 2 diabetes", "T2D", "non-insulin dependent diabetes mellitus" and "NIDDM". A librarian from University of Stirling assisted in the development of key terms, which can differ from one database to another, and advised on which databases would be more likely to produce the type of studies the review was seeking. The reference lists of all included studies were searched by hand in order to identify relevant studies that may have been missed by the strategy.

In order to select appropriate studies, specific inclusion and exclusion criteria were set. The review included published empirical quantitative and qualitative studies and systematic reviews, written in English. Studies that reported on at least one of the illness representations of the Common Sense Model [7] in patients with type 2 diabetes were included in the review. Studies were excluded if they presented opinions on a specific intervention programme; assessed the effectiveness of interventions that aim to alter perceptions of type 2 diabetes; tested the validity of the illness perception questionnaire; explored self-management behaviours among patients or reported patients' experience of living with type 2 diabetes. Study protocols were also excluded. The criteria were applied in a two-step process, which resulted in the identification of 34 studies (Figure 1). In the first step, they were applied to the titles and abstracts of the identified studies. If the relevance of a study was not clear from the abstract, the full text of the study was assessed. RefWorks was used to manage the references identified by the search. The review included empirical quantitative and qualitative studies, written in English, which reported on the perceptions of type 2 diabetes of patients with this condition. Studies were excluded if they reported opinions on a specific intervention programme or assessed the effectiveness of interventions intended to alter perceptions of type 2 diabetes; if they tested the validity of the illness perception questionnaire; if they explored self-management behaviours among patients or reported patients' experience of living with type 2 diabetes. Study protocols were also excluded. The search and identifying of studies were conducted by XX and reviewed by XX.

\section{Insert Figure 1 about here}

Data extraction included publication information, study design, sample, methods, measures (for quantitative studies) and findings/results (Table 2 and table 3 ).

Insert table 2 and table 3 about here

\section{RESULTS}

\subsection{Summary of studies}

Thirty four studies were included in this review. The majority of studies were qualitative (23) with interviews as a primary data collection method. The remaining studies were quantitative and used the Revised Illness Perceptions Questionnaire (IPQ-R) [8]. The study year ranged from 1995 to 2016 with the majority of studies conducted after 2005 . The sample size ranged from 66 to 1609 in the quantitative studies and from 7 to 46 in the qualitative studies. The mean duration of diabetes among participants varied from 2.6 weeks to 45 years. The majority of studies were conducted in the USA (12) and the UK (5). The remainder of the studies were conducted in The Netherlands (3), Brazil (2), Ireland (2), Mexico (2), Libya (1), Malaysia (1), Canada (1), Thailand (1), Germany (1), Greece (1), Ethiopia (1) and multiple countries (1).

\subsection{Population samples}

The studies in the review included patients from different countries, diverse backgrounds and certain minority groups, such as Filipino Americans living in Hawaii and Turkish immigrants living in Germany. Twelve studies included people who were not native to the country where the study was carried out. In three studies the population was described as immigrants or migrants [14-16] and in nine studies these people may have been born in that country but they were not native to it (e.g. Chinese Americans; African Americans) [17-25]. Seventeen studies included patients from the general population but in three studies, these patients were recruited from a very specific area of the country, so they cannot be considered to be representative of the population [26-28]; and in one study patients had to have been hospitalised at least twice in the previous year to take part in the study, so they were not necessarily representative of the population [29]. Only two studies included multicountry populations and compared the perceptions of people with diabetes across different countries/cultures [30, 31].

The rationale for a chosen minority population was the higher risk of type 2 diabetes when compared to the general population. Two studies mentioned the importance of individualised diabetes education programmes as the reason for including participants from a specific geographical area $[26,32]$. The rationale for comparing perceptions across countries/cultures was that perceptions of diabetes are embedded in a historical and cultural context.

The inclusion criteria across studies varied. Some studies used a self-reported measure of diabetes diagnosis while others required a formal diagnosis by a health professional. 
Language requirements and specific age range were common inclusion criteria. Self-reported identification with a certain ethnic group or nationality and a minimum duration of residence in the specific country were also used as inclusion criteria.

\subsection{Illness representations}

The results of the included studies are presented according to the illness representations components, described in Leventhal's [7] Common Sense model. The process of information summary included identifying relevant information in each study, according to the illness representation components. Information was included in the review if the authors referred explicitly to one of the components of the illness representations model. Although perceived severity of illness is part of the consequences component of the model, some studies explored severity separately, using a Likert-scale. Perceptions of severity were included in the review but they have been described separately. In addition, many studies explore diabetes knowledge. Although knowledge is different from coherence (understanding), this was included in the scoping review as knowledge appeared to affect coherence in the included studies.

\section{Identity}

Eleven studies investigated patients' perceptions of identity of type 2 diabetes $[14,16,17,23,25,26,32-36]$. The patients in three of the studies reported experiencing symptoms such as fatigue, weight loss, increased thirst and vision problems $[14,23,32]$. In one study, patients believed that the need for insulin is a symptom of type 2 diabetes [17]. They described the condition as invisible because they did not experience any symptoms and because it did not affect their daily activities. Interestingly, in three of the studies patients believed that "not feeling sick means not being sick" and if they didn't experience illness symptoms, the existence of their condition was denied [25, 26, 34]. Similarly, participants in Naemiratch \& Manderson's [35] study also described type 2 diabetes as invisible if it did not affect daily life. Participants in van Puffelen et al.'s [36] study, who did not have diabetes-related complications, also reported lack of symptoms and low impact on daily life. Low perception of identity was also reported in Ashur et al.'s [33] study (IPQ-R: $M=4.55$ ). The patients in two studies associated type 2 diabetes with sugar in the urine and believed that if there is no sugar in their urine, they do not have the illness [25].

\section{Consequences}

Sixteen studies reported on patients' perceptions of the consequences of type 2 diabetes [14-17, 21, 23, 25, 29, 32, 33, 36-39, 40, 41]. Patients reported physical (worse health status, body changes), psychosocial (voluntary and involuntary social isolation, loss of contacts, discrimination, loss of social functioning abilities, changes in social role) and financial consequences of type 2 diabetes [16]. They also expressed worries and fear of developing complications $[14,17,23,29,37]$. The patients in only one study acknowledged potential complications such as limb amputation, but they had limited understanding of the problems diabetes can cause to major organs [21]. In one study, patients said that type 2 diabetes has few effects on their daily life [41]. Some patients believed that insulin can cause complications, such as blindness $[17,23]$, while others believed that type 2 diabetes can undermine one's social image and make children less "marriageable [15] or affect people's relationships because it makes patients shorttempered [32]. Nguyen [25] showed that patients have poor knowledge of the long-term consequences and medically inadequate knowledge of type 2 diabetes complications.

The results from the quantitative studies show that patients did not report major consequences of type 2 diabetes (IPQ$\mathrm{R}: \mathrm{M}$ score $=16.23$ [33]; $\mathrm{M}=2.49$, [39]; $\mathrm{M}=2.49$, [36]). One study showed that the recollections of family members' social and general consequences of type 2 diabetes were associated with patients' own representations of social and general consequences ( $\mathrm{p}=.01$ and $\mathrm{p}=05$ respectively) [38].

\section{Severity}

Six studies reported on patients' perceptions of severity of type 2 diabetes [14, 16, 24, 30, 32, 34]. Only one study measured the mean perceived seriousness of type 2 diabetes, indicating that although it varies between countries $(\mathrm{p}<.001)$ patients do not perceive type 2 diabetes as very serious [30]. The rest of the studies demonstrated that perceptions of type 2 diabetes severity depend on other factors such as patients' age [16], acuteness of symptoms and presence of complications [14] and the need for insulin, number of tablets per day and frequency of hospital visits [24]. In one study, patients reported various perceptions of diabetes severity [34]. Some believed that type 2 diabetes is a serious disease but not for them because of current medical advances and because they didn't experience symptoms or complications ([34]. Others believed that type 2 diabetes is serious but they can control it and avoid the serious effects [34]. Finally, some patients were pessimistic about their own prognosis [34] and believed type 2 diabetes can kill them in a short period of time [32]. However, participants in Habte et al.'s [32] study also associated severity with presence of symptoms.

\section{Timeline}

Eight studies explored patients' perceptions of type 2 diabetes timeline and showed mixed results $[14,16,18,25$, $32,33,36,39]$. The majority of patients in six of the studies believed that type 2 diabetes is permanent and life-long [16, $18,25,33,36,39]$. Fifty percent of the patients in one study said that type 2 diabetes is a long term condition but some people expected it to be cured [14]. Participants in one study believed type 2 diabetes to be an acute illness [32].

\section{Cause}

Twenty one studies explored patients' perceptions of the cause of type 2 diabetes [14-16, 17, 19, 20, 21, 23-25, 27, 29, 31-33, 36, 39, 40-43]. Although patients in different studies 
placed different emphases on different factors, most of them identified heredity, diet (eating too many sweets), lack of physical activity, chance/bad luck and stress as the main causes of type 2 diabetes. Patients whose diabetes was detected through screening were less likely to identify lifestyle as the cause and more likely to believe heredity plays a causal role in the development of type 2 diabetes [41] The patients in three studies acknowledged the risk factors mentioned above but they believed that strong emotions, such as fear, anger and grief triggered the onset of their type 2 diabetes [23, 27, 32]. One study reported differences in the illness representations of Pakistani Indian people and White people with type 2 diabetes [31]. Pakistani Indian patients externalised responsibility for type 2 diabetes development and perceived the disease to be either inherited or caused by contextual factors such as British medication, unhealthy lifestyle in response to the Western culture (food availability) and stress associated with immigration. White patients internalised blame for their type 2 diabetes and believed it was associated with their personal "unhealthy" lifestyle.

\section{Control}

Sixteen studies explored patients' perceptions of type 2 diabetes control $(16,19,20,23-25,32-36,38,39,40,44$, 45]. Diabetic control was discussed either in terms of symptom avoidance or in terms of complication avoidance [34]. Patients associated type 2 diabetes with control but they were ambivalent as to whether they control the disease or the disease controls them [35]. Many patients believed that type 2 diabetes can be controlled through own behaviour, such as diet regulation and exercise [16, 23, 33, 36, 39], through medication and by health professionals $[16,24,25,36,39$, $32,33]$, through traditional home remedies [23, 25, 32] and by God $[16,25]$. Others believed that type 2 diabetes cannot be controlled $[16,20]$ but it can be cured if one denies its existence [20]. Perceptions of control appeared to be associated with the presence of family history of diabetes and patients' perceptions of control in family members with type 2 diabetes [38, 40, 44, 45].

\section{Emotional representations}

Eighteen studies explored patients' emotional representations of type 2 diabetes [14-16, 19, 21, 23, 26-28, $30,32,33,36,37,39,44,46,47]$. Patients reported a wide range of negative emotions and feelings associated with type 2 diabetes. These included shame, humiliation and guilt [15, 19, 21, 23], fear, worry, sadness and hopelessness [16, 26, $28,32,37]$ and anger and rage [28, 37]. Type 2 diabetes was associated with feelings of inferiority and loss of control over one's life [26]. One study found gender differences in emotional representations, showing that female patients reported high levels of anxiety and depression [46]. Some patients did not report major emotional impact of type 2 diabetes (IPQ-R: $\mathrm{M}$ score= 16.99, [33]; $\mathrm{M}=2.49$, [39]; $M=2.17$, [36]), concerns associated with stigma [27] or worries of complications (IPQ-R: $M=3$, [30]). Emotional representations appeared to depend on the presence of family history of diabetes, the route to diagnosis, the experience of symptoms and the beliefs about the cause of type 2 diabetes.
Patients with a family history of diabetes, in comparison to those without, were more likely to perceive diabetes as distressing, upsetting, causing fear, anger, anxiety and worry [44]. The route to diagnosis also affected emotional reactions towards type 2 diabetes [47]. Patients in the suspected diabetes route to diagnosis (symptoms $\Rightarrow$ suspected diabetes $\Rightarrow$ visit to GP and subsequent diagnosis) said they did not experience shock when diagnosed. Patents in the illness route (feeling ill $\Rightarrow$ health service contact and subsequent diagnosis) experienced a sense of relief because they perceived type 2 diabetes to be less serious than other illnesses they might have been diagnosed with. Patients in the routine route to diagnosis (absence of symptoms $\Rightarrow$ routine testing $\Rightarrow>$ diagnosis) reported that type 2 diabetes formed a wider pattern of ill health so it did not require an emotional reaction although they worried about the interaction between type 2 diabetes and other illnesses they have. Other people in this route were glad it was identified [47]. Patients who did not report symptoms said that the diagnosis came as a surprise [14].

\section{Illness knowledge and illness coherence}

Sixteen studies explored patients' understanding of type 2 diabetes [14, 16, 17, 19, 20-22, 28, 33, 36, 39, 40, 42-45]. Three studies reported the mean for illness coherence according to the illness perception questionnaire, showing fairly good understanding of type 2 diabetes (IPQ-R: M score $=16.12$, [33]; $M=3.48$, [39]; $M=3.42$, [36]). High understanding of type 2 diabetes was shown by Searle et al. [45]. Three studies demonstrated overall lack of knowledge of type 2 diabetes among patients [22, 42, 43]. Although knowledge is different from coherence, patients with inadequate knowledge appeared to have poor understanding of what type 2 diabetes means to them [22, 42, 43]. People described type 2 diabetes as confusing and scary [17] and complex and unpredictable [16]. Some talked about the concept of a "hot" and "cold" dynamic related to the regulation of body temperature and noted that high blood glucose produces "hotness" [19]. Others believed that type 2 diabetes was a punishment for something bad they have done in the past [21] and described as a death sentence, loss of normalcy and suffering [20]. Type 2 diabetes was also described as a silent disease because patients believed it does not cause any pain or affect people much [28]. Patients in one study described type 2 diabetes as a social disease because it may lead to people being labelled differently [14].Illness coherence may depend on the presence of family history [44]. Scollan-Koliopoulos et al. [44] found a significant difference in illness coherence between patients with family history of diabetes and patients without $(\mathrm{p}=.043)$. Patients with a family history of diabetes reported less understanding of type 2 diabetes in comparison to patients without family history of diabetes [44].

\section{DISCUSSION}

This review provides a comprehensive narrative account of previous research exploring the illness representations of type 2 diabetes among people with the condition. Following 
the Common Sense Model [7] the review shows that patients with type 2 diabetes do not always experience symptoms and as a result they perceive type 2 diabetes as an invisible illness. In addition, knowledge of symptoms is poor in some ethnic groups. Although many patients report that type 2 diabetes is a chronic illness, which can be controlled through personal behaviour, folk beliefs about denying its existence and relying on God to control it were reported. Perceptions of consequences, seriousness and understanding of type 2 diabetes varied across studies. Emotional representation of type 2 diabetes also varied across studies but most patients associated type 2 diabetes with negative emotions. Finally, knowledge of causes of type 2 diabetes was fairly good with the exception of some ethnic groups. These mixed findings have implications for evidence-based care. Individual representations of illness are closely linked with diabetes self-management $[7,9,10]$ and later use of health care [48]. Harvey and Lawson [10] provide a review of the effect of illness representations on self-management behaviours, such as physical activity, diet and glycaemic control in people with type 1 and type 2 diabetes. For example, perceived control and good understanding of type 2 diabetes predict better adherence to prescribed regimen. Perception of internal cause (attributed to self) of type 2 diabetes was also linked with better glycaemic control. Similar associations have been observed in patients with hypertension [49]. Chen [49] argues that medication adherence can be influenced by perceived cause and control over the disease. Perception of illness-related symptoms is also important for selfmanagement as patients often use perceived symptoms as a guide for medication use [50]. This is particularly problematic as type 2 diabetes can be asymptomatic for many years. Similarly, patients with hypertension, which can also be asymptomatic, are less likely to adhere to treatment regimens if they do not experience symptoms $[50,51]$. This highlights the need for interventions designed to change dysfunctional illness representations in order to improve self-management of type 2 diabetes. However, translating research findings on illness representations into interventions is challenging and further complicated by the fact that illness representations depend on ethnicity and culture. For example, some people believe that type 2 diabetes is caused by strong emotions and is controlled by God or cured using home remedies or by denying its existence $[16,20,23,25$, 27]. Certain ethnic groups may be more likely to focus on social consequences of diabetes, such as social isolation and making children less "marriageable" $[15,16]$, rather than health consequences. Additionally, immigrants often attribute the cause of type 2 diabetes to external factors, related to acculturation to Western lifestyles (e.g. food availability, stress) [31]. These findings show that the impact of illness representations on behaviour may depend on cultural values. It highlights the need for potential diabetes management interventions to incorporate cultural values and the resulting illness representations. Although such research is important for understanding poor diabetes selfmanagement in those groups, the difference between illness perceptions of the general population and ethnic minorities can reduce generalisability and limit the potential effectiveness of health promotion interventions aimed at the general population.
A comprehensive approach was taken to scoping a variety of sources to summarise knowledge of illness perceptions of type 2 diabetes among patients with type 2 diabetes. The inclusion of steps such as developing a search strategy in consultation with a librarian, searching for studies with different designs and population samples and having two reviewers for every full source have added rigour to the scoping review process. However, the review has three limitations. The first is that the review included studies with very specific populations, such as people from a specific community in Oaxaca, Mexico, Filipino Americans in Hawaii, Turkish immigrants in Germany, and patients with type 2 diabetes, who have experienced hospital readmission. As a result the generalisability of the review findings may be reduced as these factors may shape people's illness perceptions. The second limitation of the review is that there is inconsistency across the included studies in measuring illness representations with studies measuring from one to six of the illness representation components. Finally, many studies in this review used convenience sampling which reduces the generalisability of the results.

\section{CONCLUSION}

The current review shows that a one-size-fits-all approach in improving type 2 diabetes outcomes may not be possible so programmes should be relevant to the target population. The large gap in previous research limits the potential of previous findings to be used as the basis of interventions that aim to improve self-management in people with type 2 diabetes. More studies comparing illness perceptions of people from different countries and cultures are needed to shed further light into the subjective understanding of chronic illness and aid the development of effective education programmes.

\section{CONFLICT OF INTEREST}

This work was supported by the Economic and Social Research Council (ESRC). The authors wish to declare no conflict of interest.

\section{REFERENCES}

[1] Cramer JA. A systematic review of adherence with medications for diabetes. Diabet Care 2004; 27:1218-1224.

[2] World Health Organisation (WHO). Global report on diabetes 2016. France: World Health Organization.

[3] NICE (2015). Type 2 diabetes in adults: management. Available from https://www.nice.org.uk/guidance/ng28 (Retrieved on 02.06. 2017).

[4] World Health Organisation (WHO). Prevention and control of noncommunicable diseases: guidelines for primary health care in lowresource settings 2012. Geneva: WHO.

[5] Donnan P, MacDonald T, Morris A for the DARTS/MEMO Collaboration. Adherence to prescribed oral hypoglycaemic medication in a 


\section{Journal Name, 2014, Vol. 0, No. 0}

population of patients with Type 2 diabetes: a retrospective cohort study. Diabet med 2002; 19: 279-284.

[6] Norris S, Lau J, Smith S, Schmid C, Engelau M. Self-management education for adults with type 2 diabetes. A meta-analysis of the effect on glycemic control. Diabet Care 2002; 25: 1159-1171.

[7] Leventhal H, Benyanimi Y, Brownlee S, Diefenback M, Leventhal E, Patrick-Miller L, Robitaille C. Illness representations: Theoretical foundations. In Weinman J. \& Petrie, K. (Eds.), Perceptions of Health and Illness. London: Harwood Publishers, 1997.

[8] Moss-Morris R, Weinman J, Petrie K, Horne R, Cameron L, Buick D. The revised illness perception questionnaire (IPQ-R). Psychol Health 2002; 17 (1): 1-16.

[9] Glasgow R, Strycker L, Hampson S, Ruggiero L. Personal-model beliefs and social-environmental barriers related to diabetes self-management. Diabet Care 1997; 20 (4): 556.

[10] Harvey JN, Lawson VL. The importance of health belief models in determining selfcare behaviour in diabetes. Diabet Med 2009; 26:5-13.

[11] Arksey H, O’Malley L. Scoping studies: Towards a methodological framework. Int J Soc Res Methodol 2005; 19-32, ISSN1364-5579.

[12] Levac D, Colquhoun H, O'Brien K. Scoping studies: Advancing the methodology. Implement Sci 2010; 5:69.

[13] Moher D, Liberati A, Tetzlaff J, Altman D, PRISMA group. Preferred reporting items for systematic reviews and meta-analyses: the PRISMA statement. PLoS One Medicine 2009; 6.

[14] Jayne R, Rankin S. Application of Leventhal's Self- Regulation Model to Chinese Immigrants With Type 2 Diabetes. J Nurs Sch 2001;33(1):53-59.

[15] Pistulka G, Winch P, Park H, Han H, Kim M. Maintaining an Outward Image: A Korean Immigrant's Life With Type 2 Diabetes Mellitus and Hypertension. Qual Health Res 2012;22(6):825-834.

[16] Yilmaz-Aslan Y, Brzoska P, Bluhm M, Aslan A, Razum O. Illness perceptions in Turkish migrants with diabetes: A qualitative study. Chronic Illn 2014;10(2):107-121.

[17] Alcozer F. Secondary analysis of perceptions and meaning of type 2 diabetes among Mexican American women. Diabetes Educ 2000;26(5):785795.

[18] Calvin D, Quinn L, Dancy B, Park C, Fleming S, Smith E, et al. African Americans' Perception of Risk for Diabetes Complications. Diabetes Educ 2011;37(5):689-698.

[19] Chun K, Chesla C. Cultural issues in disease management for Chinese Americans with type 2 diabetes. Psychol Health 2004;19(6):767-785.

[20] Egede L, Bonadonna R. Diabetes self-management in African Americans: an exploration of the role of fatalism. Diabetes Educ 2003;29(1):105-115.

[21] Finucane M, McMullen C. Making Diabetes Self-management Education Culturally Relevant for Filipino Americans in Hawaii. Diabetes Educ 2008; 34(5):841-853.

[22] Hernandez C, Antone R, Cornelius I. A Grounded Theory Study of the Experience of Type 2 Diabetes Mellitus in First Nations Adults in Canada. J Transcult Nurs 1999;10(3):220-228.

[23] Jezewski M, Poss J. Mexican Americans' Explanatory Model of Type 2 Diabetes. Western J Nurs Res 2002;24(8):840-858.
[24] Macaden L, Clarke C. Risk perception among older South Asian people in the UK with type 2 diabetes. Int J Older People Nurs 2006;1:177-181.

[25] Nguyen A. Self-Management of Type 2 Diabetes: Perspectives of Vietnamese Americans. J Transcult Nurs 2014;25(4):357-363.

[26] Dietrich U. Factors influencing the attitudes held by women with type II diabetes: a qualitative study. Patient Educ Couns 1996;29:13-23.

[27] Everett M. They say it runs in the family: Diabetes and inheritance in Oaxaca, Mexico. Soc Sci Med 2011;72:1776-1783.

[28] Péres D, Franco L, Santos M. Feelings of women after the diagnosis of type 2 diabetes. Rev Lat Am Enfermagem 2008;16(1):101-108.

[29] Baggio S, Santos A, Sales C, Marcon S. Perception of people suffering from diabetes regarding the disease and the reasons for hospital readmission: a descriptive study. OBJN 2013;12(3).

[30] Hajos T, Polonsky W, Twisk J, Dain M, Snoek F. Do physicians understand Type 2 diabetes patients' perceptions of seriousness; the emotional impact and needs for care improvement? A cross-national survey. Pat Educ Couns 2011;85:258-263. 
[31] Lawton J, Ahmad N, Peel EH. Contextualising accounts of illness: notions of responsibility and blame in white and South Asian respondents' accounts of diabetes causation. Sociol Health Illn 2007;29(6):891-906.

[32] Habte B, Kebede T, Fenta T, Boon H. Explanatory models of adult patients with type 2 diabetes mellitus from urban centers of central Ethiopia. BMC Research Notes 2016; 9 (441).

[33] Ashur S, Shah S, Bosseri S, Morisky D, Shamsuddin K. Illness perceptions of Libyans with T2DM and their influence on medication adherence: a study in a diabetes center in Tripoli. Libyan J Med 2015; 10, 29797.

[34] Murphy E, Kinmonth A. No symptoms, no problem? Patients' understandings of non-insulin dependent diabetes. Fam Pract 1995;12(2):184-192.

[35] Naemiratch B, Manderson L. Control and adherence: Living with diabetes in Bangkok, Thailand. Soc Sci Med 2006;63:1147-1157.

[36] Van Puffelen, A., Heijmans, M., Rijken, M., Rutten, G. Schellevison, F on behalf of the Diacourse study group (2015). Illness perceptions and selfcare behaviours in the first years of living with type 2 diabetes; does the presence of complications matter?, Psychol Health, 30:11, 1274-1287.

[37] Hughes L, Keith S, Byars A, Wiginton K. Cognitive Mapping in Persons Newly Diagnosed With Type 2 Diabetes. Diabetes Educ 2012;38(6):845-854.

[38] Scollan-Koliopoulos M, O'Connell K, Walker E. Legacy of Diabetes and Self-care Behavior. Res Nurs Health 2007; 30:508-517.

[39] Van Esch S, Nijkamp M, Cornel M, Snoek F. Illness representations of type 2 diabetes patients are associated with perceptions of diabetes threat in relatives. J Health Psychol 2014;19(3):358-368.

[40] White P, Smith S, Hevey D, O'Dowd T. Understanding Type 2 Diabetes Including the Family Member's Perspective. Diabetes Educ 2009;35(5):810-817.

[41] Woolthuis E, de Grauw W, Cardol M, van Weel C, Metsemakers J, Biermans M. Patients' and partners' illness perceptions in screendetected versus clinically diagnosed type 2 diabetes: partners matter! Fam Pract 2013;30:418-425.

[42] Al-Qazaz H, Hassali M, Shafie A, Sulaiman S, Sundram S. Perception and knowledge of patients with type 2 diabetes in Malaysia about their disease and medication: A qualitative study. Res Social and Adm Pharm 2011;7:180-191.

[43] White P, Smith M, O'Dowd T. Living with type 2 diabetes: A family perspective. Diabet Med 2007; 24, 796-801.

[44] Scollan-Koliopoulos M, Walker E, Rapp III K. Self-regulation Theory and the Multigenerational Legacy of Diabetes. Diabetes Educ 2011; 37(5):669-679.

[45] Searle A, Norman P, Thompson R, Vedhara K. Illness representations among patients with type 2 diabetes and their partners: Relationships with self-management behaviors. J Psychosom Res 2007;63:175-184.

[46] Dimitraki G, Karademas E. The Association of Type 2 Diabetes Patient and Spouse Illness Representations with Their Well-being: A Dyadic Approach. Int J Beh Med 2014; 21:230-239.

[47] Peel E, Parry O, Douglas M, Lawton J. Diagnosis of type 2 diabetes: a qualitative analysis of patients' emotional reactions and views about information provision. Pat Educ Couns 2004;53:269-275.

[48] Frostholm L, Fink P, Christensen KS, Toft T, Oernboel E, Olessen F et al. The patients' illness perceptions and the use of primary health care. Psychosom Med 2005; 67(6), 997-1005.

[49] Chen SH, Tsai JC, Chou KR Illness perceptions and adherence to therapeutic regimens among patients with hypertension: A structural modelling approach. Int J Nurs St 2011; 48: 235-245.

[50] Petrie K, Weinman, J. Why illness perceptions matter. Clin Med 2006; 6:536-539.

[51] Ross S, Walker A, MacLeod MJ. Patient complience in hypertension: role of illness perceptions and treatment beliefs. J Hum Hypertens 2004; 18:607-613. 
8 Journal Name, 2014, Vol. 0, No. 0 


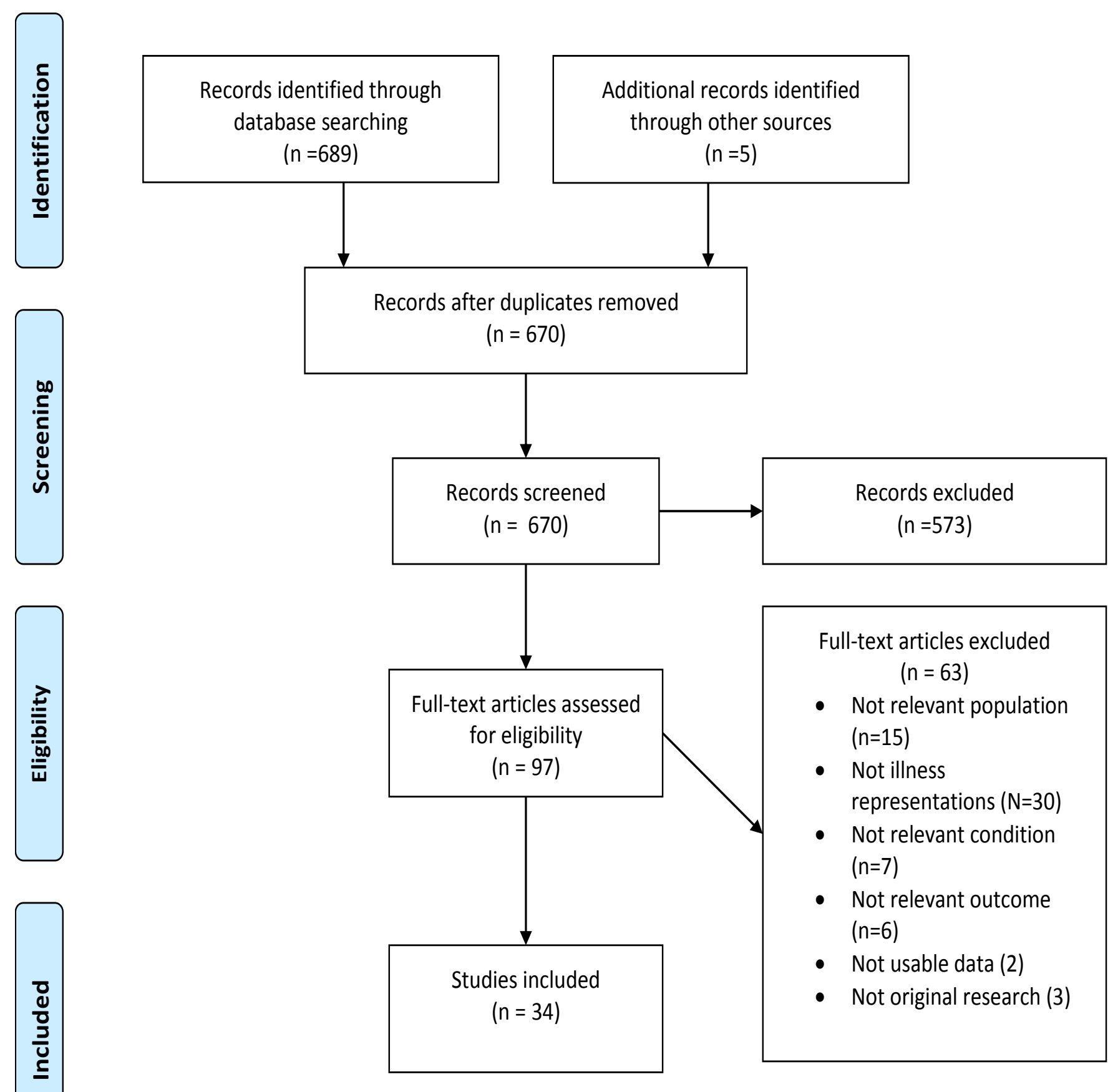

Figure 1. Identification and selection of studies (Adapted from Moher, Liberati, Tetxlaff, Altman \&The Preferred Reporting Items for Systematic Reviews and Meta-Analyses (PRISMA) Group, 2009) [13]. 
Table 1

Table 1: Illness representation components. Adapted from Leventhal et al. (1992) and Illness Perception Questionnaire (Weinman et al., 1996).

\begin{tabular}{|c|c|c|}
\hline $\begin{array}{l}\text { Illness representation } \\
\text { component }\end{array}$ & Description & Example \\
\hline Identity & $\begin{array}{l}\text { The label, given to the condition } \\
\text { and its symptoms. }\end{array}$ & $\begin{array}{l}\text { "The fact that I feel tired all the } \\
\text { time is a sign of type } 2 \text { diabetes" }\end{array}$ \\
\hline Consequences & $\begin{array}{l}\text { Individual's beliefs about the } \\
\text { consequences (e.g. physical, } \\
\text { emotional, social) of the illness. }\end{array}$ & $\begin{array}{l}\text { "Type } 2 \text { diabetes is a serious } \\
\text { condition" }\end{array}$ \\
\hline Timeline & $\begin{array}{l}\text { The perception of the illness as } \\
\text { acute or chronic. }\end{array}$ & $\begin{array}{l}\text { "My type } 2 \text { diabetes will last for a } \\
\text { long time" }\end{array}$ \\
\hline Cause & $\begin{array}{l}\text { The individual's perception of the } \\
\text { cause of the illness. }\end{array}$ & "Stress caused my disease" \\
\hline Control & $\begin{array}{l}\text { Beliefs about whether the } \\
\text { condition can be cured or } \\
\text { controlled. }\end{array}$ & $\begin{array}{l}\text { "There is little that can be done to } \\
\text { improve my illness" }\end{array}$ \\
\hline Emotional representation & $\begin{array}{l}\text { The emotions people experience } \\
\text { in response to their illness. }\end{array}$ & $\begin{array}{l}\text { "Type } 2 \text { diabetes makes me feel } \\
\text { afraid" }\end{array}$ \\
\hline Illness coherence & $\begin{array}{l}\text { People's subjective understanding } \\
\text { of their disease. }\end{array}$ & $\begin{array}{l}\text { "My type } 2 \text { diabetes doesn't make } \\
\text { any sense to me" }\end{array}$ \\
\hline
\end{tabular}


Accepted for publication in Current Diabetes Reviews. The published manuscript is available at

EurekaSelect via http://www.eurekaselect.com/openurl/content.php?genre=article\&doi=10.2174/1573399814666171227214845

Table 2 Summary of Included Quantitative studies

\begin{tabular}{|c|c|c|c|c|c|c|}
\hline Author and year & $\begin{array}{lcc}\text { Study aim(s) } & \text { as } \\
\text { relevant to } & \text { the } \\
\text { current review } & \end{array}$ & Country & $\begin{array}{l}\text { Participants } \\
\text { (number } \\
\text { characteristics) }\end{array}$ & Design & Measure(s) & Results \\
\hline Ashur et al. (2015) & $\begin{array}{l}\text { To assess diabetes } \\
\text { illness perceptions } \\
\text { among Libyans with } \\
\text { type } 2 \text { diabetes } \\
\text { mellitus (T2DM) }\end{array}$ & Libya & $\begin{array}{l}\mathrm{N}=523 \\
\text { Age: } \mathrm{M}=54.3 \text { years } \\
\text { Gender: } 215 \text { male, } \\
308 \text { female } \\
\text { Education: } 304 \\
\text { Primary, } 219 \\
\text { secondary or higher } \\
\text { Occupation: } 142 \\
\text { employed, } 381 \\
\text { unemployed } \\
\text { Marital status: } 121 \\
\text { not married, } 402 \\
\text { married } \\
\text { Diabetes duration: } \\
\text { M=9.4 years }\end{array}$ & Cross-sectional study & $\begin{array}{l}\text { Illness Perception } \\
\text { Questionnaire (IPQ- } \\
\text { R) }\end{array}$ & $\begin{array}{l}\text { Identity: Low } \\
\text { perception, attributing } \\
\text { few symptoms to } \\
\text { diabetes (M=4.55) } \\
\text { Consequences: } \\
\text { Moderate perception } \\
\text { (M=16.24) } \\
\text { Timeline: High } \\
\text { perception of type } 2 \\
\text { diabetes as a chronic } \\
\text { illness (M=22.08) and } \\
\text { moderate perception } \\
\text { as a cyclical illness } \\
\text { (M=12.42) } \\
\text { Cause: } \text { Most } \\
\text { commonly mentioned } \\
\text { Allah/fate, followed } \\
\text { by heredity, emotional } \\
\text { state, family } \\
\text { problems/worries and } \\
\text { diet/eating habits. } \\
\text { Control: High } \\
\text { perception of personal } \\
\text { control (M=18.93) } \\
\text { and control through } \\
\text { treatment (M=19.19) } \\
\text { Emotional } \\
\text { representations: } \\
\text { Moderate }\end{array}$ \\
\hline
\end{tabular}


Journal Name, 2014, Vol. O, No. 013

\begin{tabular}{|c|c|c|c|c|c|c|}
\hline Author and year & $\begin{array}{lcr}\text { Study } & \operatorname{aim}(s) & \text { as } \\
\text { relevant to } & \text { the } \\
\text { current review } & \end{array}$ & Country & $\begin{array}{l}\text { Participants } \\
\text { (number } \\
\text { characteristics) }\end{array}$ & Design & Measure(s) & Results \\
\hline & & & & & & $\begin{array}{l}\text { perception }(\mathrm{M}=16.99) \\
\text { Illness coherence: } \\
\text { Moderate }(\mathrm{M}=16.12)\end{array}$ \\
\hline $\begin{array}{l}\text { Calvin, Quinn, Dancy, } \\
\text { Park, Fleming, Smith } \\
\& \text { Fogelfeld (2011) }\end{array}$ & $\begin{array}{l}\text { To explore perceived } \\
\text { risk for diabetes } \\
\text { complications among } \\
\text { urban African } \\
\text { American adults (18- } \\
75 \text { years old) with } \\
\text { type } 2 \text { diabetes }\end{array}$ & USA & $\begin{array}{l}\mathrm{N}=143 \\
\text { Age: } \mathrm{M}=52.8 \text { years } \\
\text { Gender: } 53.1 \% \\
\text { women } \\
\text { Education: } \mathrm{M}=12.2 \\
\text { years } \\
\text { Occupation: Not } \\
\text { reported } \\
\text { Marital status: Not } \\
\text { reported } \\
\text { Diabetes duration: } \\
\text { M= } 1.95 \text { years }\end{array}$ & $\begin{array}{l}\text { Exploratory, } \\
\text { descriptive, } \\
\text { correlational, cross- } \\
\text { sectional }\end{array}$ & $\begin{array}{l}\text { Risk Perception } \\
\text { Survey-Diabetes } \\
\text { Mellitus } \\
\text { 12-item Well-being } \\
\text { Questionnaire } \\
\text { Illness Perception } \\
\text { Questionnaire (IPQ- } \\
\text { R) } \\
\text { Blood gas analyser for } \\
\text { A1C } \\
\text { Blood pressure }\end{array}$ & $\begin{array}{l}\text { Consequences: } \\
\text { Diabetes } \\
\text { complications } \\
\mathrm{M}=2.58 \text { (range } 1-4) \text {. } \\
\text { Timeline: } 65 \% \text { did not } \\
\text { see diabetes as a } \\
\text { permanent condition }\end{array}$ \\
\hline $\begin{array}{l}\text { Dimitraki \& } \\
\text { Karademas (2014) }\end{array}$ & $\begin{array}{l}\text { To examine the } \\
\text { relation between } \\
\text { certain illness } \\
\text { representations and } \\
\text { the physical and } \\
\text { psychological well- } \\
\text { being of persons with } \\
\text { type } 2 \text { diabetes } \\
\text { mellitus and their } \\
\text { spouses }\end{array}$ & Greece & $\begin{array}{l}\mathrm{N}=84 \\
\text { Age: } \mathrm{M}=64.65 \text { years } \\
\text { Gender: } 55 \text { women, } \\
29 \text { men } \\
\text { Education: } 62 \% \text { nine } \\
\text { year mandatory } \\
\text { education or less; } \\
16.70 \% \text { high school; } \\
21.30 \% \text { higher } \\
\text { education. } \\
\text { Occupation: not } \\
\text { reported } \\
\text { Marital status: } \\
\text { Marriage duration of }\end{array}$ & $\begin{array}{l}\text { Hypothesis testing, } \\
\text { questionnaires, } \\
\text { Actor-Partner } \\
\text { Independence model } \\
\text { (APIM) }\end{array}$ & $\begin{array}{l}\text { Illness Perception } \\
\text { Questionnaire (IPQ- } \\
\text { R) } \\
\text { General Health Scale } \\
\text { from the RAND 36- } \\
\text { item health survey } \\
\text { The Hospital Anxiety } \\
\text { and Depression Scale }\end{array}$ & $\begin{array}{l}\text { Emotional } \\
\text { representations: } \\
\text { Gender difference in } \\
\text { emotional } \\
\text { representations. } \\
\text { There is a relationship } \\
\text { between perceptions } \\
\text { of patients and their } \\
\text { spouses. }\end{array}$ \\
\hline
\end{tabular}




\begin{tabular}{|c|c|c|c|c|c|c|}
\hline Author and year & $\begin{array}{l}\text { Study aim(s) as } \\
\text { relevant to } \\
\text { current review }\end{array}$ & Country & $\begin{array}{l}\text { Participants } \\
\text { (number } \\
\text { characteristics) }\end{array}$ & Design & Measure(s) & Results \\
\hline & & & $\begin{array}{l}27.39 \text { years } \\
\text { Diabetes duration: } \\
14.94 \text { years }\end{array}$ & & & \\
\hline $\begin{array}{l}\text { Hajos, Polonsky, } \\
\text { Twisk, Dain \& Snoek } \\
\text { (2011) }\end{array}$ & $\begin{array}{l}\text { To explore across } \\
\text { countries the extent to } \\
\text { which physicians } \\
\text { understand Type } 2 \\
\text { diabetes patients' } \\
\text { perceptions of } \\
\text { seriousness, worries } \\
\text { about complications, } \\
\text { emotional distress, } \\
\text { and needs for care } \\
\text { improvement. }\end{array}$ & $\begin{array}{l}\text { France, Germany, } \\
\text { UK, Italy, the } \\
\text { Netherlands, Spain, } \\
\text { Sweden, USA }\end{array}$ & $\begin{array}{l}\mathrm{N}=1609 \\
\text { Age: } \mathrm{M}=51.4 \\
\text { Gender: } 41 \% \text { female } \\
\text { Education: not } \\
\text { reported } \\
\text { Occupation: not } \\
\text { reported } \\
\text { Marital status: Not } \\
\text { reported } \\
\text { Diabetes duration: } \\
\text { M=6.5 }\end{array}$ & Cross-national survey & $\begin{array}{l}\text { Perceived seriousness } \\
\text { Diabetes-related } \\
\text { distress: worried, } \\
\text { afraid, overwhelmed, } \\
\text { would benefit from } \\
\text { psychological } \\
\text { support, angry } \\
\text { Worries about } \\
\text { complications: eye } \\
\text { damage, kidney } \\
\text { damage, } \\
\text { cardiovascular } \\
\text { complications, leg } \\
\text { problems, foot } \\
\text { sensitivity disorders, } \\
\text { sexual disorders, } \\
\text { amputations. }\end{array}$ & $\begin{array}{l}\text { Severity: Moderate } \\
\text { perceived seriousness } \\
=(\mathrm{M}=2.4) \text { (country } \\
\text { differences noted }) \\
\text { Consequences: } \\
\text { Worries about } \\
\text { complications }(\mathrm{M}=3) \text {. } \\
\text { Worries about } \\
\text { complications were } \\
\text { significantly and } \\
\text { positively related to } \\
\text { perceived seriousness. }\end{array}$ \\
\hline $\begin{array}{l}\text { Scollan-Koliopoulos, } \\
\text { Walker \& Rapp III, } \\
2011\end{array}$ & $\begin{array}{l}\text { To test if T2D } \\
\text { patients with and } \\
\text { without family history } \\
\text { of T2D have different } \\
\text { illness representations }\end{array}$ & USA & $\begin{array}{l}\mathrm{N}=100 \\
\text { Age: range } 21-90 \\
\text { (mainly } 71-80 \text { years) } \\
\text { Gender: not reported } \\
\text { Education: } 18^{\text {th }}-9^{\text {th }} \\
\text { grade, } 1912^{\text {th }} \text { grade, } 8 \\
\text { technical, } 23 \text { some } \\
\text { college/trade, } 294- \\
\text { year college } \\
\text { Occupation: not } \\
\text { reported } \\
\text { Marital status: not } \\
\text { reported }\end{array}$ & $\begin{array}{l}\text { Hypothesis testing, } \\
\text { surveys. }\end{array}$ & $\begin{array}{l}\text { Illness Perception } \\
\text { Questionnaire- } \\
\text { Diabetes Version } \\
\text { Summary of Diabetes } \\
\text { Self-care Behaviour } \\
\text { (SDSC) }\end{array}$ & $\begin{array}{l}\text { Emotional } \\
\text { representations: } \\
\text { distressing, upsetting, } \\
\text { causing fear, anger, } \\
\text { anxiety and worry. } \\
\text { Illness coherence: } \\
\text { poor understanding of } \\
\text { diabetes and } \\
\text { perceiving it is } \\
\text { unpredictable. } \\
\text { Significant difference } \\
\text { between people with } \\
\text { and without family } \\
\text { history of diabetes on } \\
\text { personal control }\end{array}$ \\
\hline
\end{tabular}


Journal Name, 2014, Vol. 0, No. 015

\begin{tabular}{|c|c|c|c|c|c|c|}
\hline Author and year & $\begin{array}{l}\text { Study aim(s) as } \\
\text { relevant to } \\
\text { current review }\end{array}$ & Country & $\begin{array}{l}\text { Participants } \\
\text { (number } \\
\text { characteristics) }\end{array}$ & Design & Measure(s) & Results \\
\hline & & & $\begin{array}{l}\text { Diabetes duration: } \\
\text { not reported }\end{array}$ & & & $\begin{array}{l}(\mathrm{p}=.001), \text { treatment } \\
\text { control }(\mathrm{p}=, 001), \\
\text { emotional } \\
\text { representations } \\
(\mathrm{p}=.048) \text { and illness } \\
\text { coherence }(\mathrm{p}=.043)\end{array}$ \\
\hline $\begin{array}{l}\text { Scollan-Koliopoulos, } \\
\text { O'Connell \& Walker } \\
\text { (2007) }\end{array}$ & $\begin{array}{l}\text { To test the hypothesis } \\
\text { that the ways in which } \\
\text { family members with } \\
\text { T2D viewed } \\
\text { controllability, } \\
\text { consequences and } \\
\text { stigma of diabetes } \\
\text { would be positively } \\
\text { related to target } \\
\text { patients' perceptions } \\
\text { of controllability, } \\
\text { consequences and } \\
\text { stigma }\end{array}$ & USA & $\begin{array}{l}\mathrm{N}=123 \\
\text { Age: range 41-90 } \\
\text { Gender: } 59 \text { women, } \\
59 \text { men } \\
\text { Education: } 39^{\text {th }} \\
\text { grade or lower, } 29 \\
12^{\text {th }} \text { grade or GED, } 7 \\
\text { graduate technical, } 33 \\
\text { some college/trade, } 50 \\
\text { 4-year college } \\
\text { Occupation: not } \\
\text { reported } \\
\text { Marital status: not } \\
\text { reported } \\
\text { Diabetes duration: } \\
\text { M=8.85 years }\end{array}$ & $\begin{array}{l}\text { Hypothesis testing, } \\
\text { surveys }\end{array}$ & $\begin{array}{l}\text { Recollections of } \\
\text { family illness } \\
\text { perception } \\
\text { questionnaire } \\
\text { Illness perception } \\
\text { questionnaire (IPQ-R) } \\
\text { Summary of diabetes } \\
\text { self-care activities } \\
\text { survey } \\
\text { Demographic } \\
\text { questions }\end{array}$ & $\begin{array}{l}\text { Cause: } 90 \% \text { reported } \\
\text { heredity. } \\
\text { Relationship between } \\
\text { perceptions of control } \\
\text { and consequences of } \\
\text { patients and their } \\
\text { relatives. }\end{array}$ \\
\hline $\begin{array}{l}\text { Searle, Norman, } \\
\text { Thompson \& } \\
\text { Vedhara, } 2007\end{array}$ & $\begin{array}{l}\text { To assess the illness } \\
\text { representations of } \\
\text { T2D patients and their } \\
\text { partners }\end{array}$ & UK & $\begin{array}{l}\mathrm{N}=164 \\
\text { Age: } \mathrm{M}=67 \\
\text { Gender: } 97 \text { male, } 67 \\
\text { female } \\
\text { Education: Age they } \\
\text { left school: } 28 \text { at } 14 \\
\text { yrs, } 32 \text { at } 15 \text { yrs, } 25 \text { at } \\
16 \text { yrs, } 15 \text { at other } \\
\text { age; } \\
\text { Occupation: patients: }\end{array}$ & $\begin{array}{l}\text { Cross-sectional, } \\
\text { questionnaires at } \\
\text { baseline and at } 12 \\
\text { months }\end{array}$ & $\begin{array}{l}\text { Illness perception } \\
\text { questionnaire (IPQ-R) } \\
\text { Personal models of } \\
\text { diabetes interview } \\
\text { (PDMI) }\end{array}$ & $\begin{array}{l}\text { Identity: High blood } \\
\text { glucose }(\mathrm{M}=3.20) \text {, } \\
\text { low blood glucose } \\
(\mathrm{M}=3.16) \text {. } \\
\text { Consequences: } \\
\text { Moderate perception } \\
\text { of seriousness } \\
(\mathrm{M}=17.2) \\
\text { Timeline: Acute } \\
(\mathrm{M}=23.3) \text {, Cyclical }\end{array}$ \\
\hline
\end{tabular}




\begin{tabular}{|c|c|c|c|c|c|c|}
\hline Author and year & $\begin{array}{l}\text { Study aim(s) as } \\
\text { relevant to } \\
\text { current review }\end{array}$ & Country & $\begin{array}{l}\text { Participants } \\
\text { (number } \\
\text { characteristics) }\end{array}$ & Design & Measure(s) & Results \\
\hline & & & $\begin{array}{l}54 \text { retired, } 10 \\
\text { professional, } 32 \\
\text { semiskilled manual, } 4 \\
\text { unemployed. } \\
\text { Marital status: } \mathrm{N} \\
\text { years living } \\
\text { together/married } \\
\mathrm{M}=35.6 \\
\text { Diabetes duration: } \\
\text { mean=8.8 years, } \\
\text { range } 6 \text { months to } 38 \\
\text { years }\end{array}$ & & & $\begin{array}{l}\text { (11.1) } \\
\text { Cause: Own } \\
\text { behaviour }(\mathrm{M}=14.4) \text {, } \\
\text { External }(\mathrm{M}=12.7), \\
\text { Hereditary }(\mathrm{M}=3.2) \\
\text { Control: Personal } \\
\text { control }(\mathrm{M}=23.4) \text {, } \\
\text { treatment control } \\
(\mathrm{M}=22.9) \\
\text { Emotional } \\
\text { representation: } \\
\text { Moderate }(\mathrm{M}=12.1) \\
\text { Illness coherence: } \\
\text { High }(\mathrm{M}=17.5)\end{array}$ \\
\hline $\begin{array}{l}\text { van Esch, Nijkamp, } \\
\text { Cornel \& Snoek } \\
\text { (2014) }\end{array}$ & $\begin{array}{l}\text { To explore patients' } \\
\text { illness representations }\end{array}$ & The Netherlands & $\begin{array}{l}\text { N=546 } \\
\text { Age: M=63.6 } \\
\text { Gender: } 272 \text { men, } \\
274 \text { women } \\
\text { Education: } 336 \text { low, } \\
\text { 186 high } \\
\text { Marital status: } 180 \\
\text { living alone, } 350 \\
\text { cohabiting } \\
\text { Ethnicity: } 311 \text { Dutch, } \\
\text { 157 Surinamese South } \\
\text { Asian, } 72 \text { other } \\
\text { Diabetes duration: } \\
\text { 241 <5yrs, } 1155 \text { - } \\
\text { 10yrs, } 187>10 y r s .\end{array}$ & $\begin{array}{l}\text { Cross-sectional } \\
\text { survey }\end{array}$ & $\begin{array}{l}\text { Illness representations } \\
\text { questionnaire (IPQ-R) }\end{array}$ & $\begin{array}{l}\text { Consequences: } \\
\text { Patients did not report } \\
\text { major consequences } \\
\text { (M=2.49). } \\
\text { Timeline: Strong } \\
\text { beliefs about } \\
\text { chronicity (M=4) } \\
\text { Cause: Most endorsed } \\
\text { causes of T2D: } \\
\text { Heredity-61.3\% } \\
\text { Ageing-49.4\% } \\
\text { Diet - 44.5\% } \\
\text { Stress-40.4\% } \\
\text { Lack of exercise- } \\
37.4 \% \\
\text { Chance/bad luck- } \\
36.7 \% \\
\text { Own behaviour- } \\
25.3 \% \\
\text { Family problems- } \\
22.9 \% \\
\text { Altered immunity- }\end{array}$ \\
\hline
\end{tabular}


Journal Name, 2014, Vol. O, No. 017

\begin{tabular}{|c|c|c|c|c|c|c|}
\hline Author and year & $\begin{array}{lcr}\text { Study aim(s) as } \\
\text { relevant to } \\
\text { current review }\end{array}$ & Country & $\begin{array}{l}\text { Participants } \\
\text { (number } \\
\text { characteristics) }\end{array}$ & Design & Measure(s) & Results \\
\hline & & & & & & $\begin{array}{l}21.6 \% \\
\text { Control: } \text { Strong } \\
\text { beliefs about the } \\
\text { effectiveness of } \\
\text { controlling it by own } \\
\text { behaviour (M=3.60) } \\
\text { and by medication } \\
(\mathrm{M}=3.67) \text {. } \\
\text { Illness coherence: } \\
\text { Good understanding } \\
(\mathrm{M}=3.48) \text {. They did } \\
\text { not perceive T2D as } \\
\text { unpredictable } \\
\text { (M=2.74). } \\
\text { Emotional } \\
\text { representation: Low } \\
\text { emotional impact } \\
\text { (M=2.49). }\end{array}$ \\
\hline $\begin{array}{l}\text { Van Puffelen, } \\
\text { Heijmans, Rijken, } \\
\text { Rutten, Nijpels \& } \\
\text { Schellevison on } \\
\text { behalf of the } \\
\text { Diacourse study } \\
\text { group (2015) }\end{array}$ & $\begin{array}{l}\text { To assess illness } \\
\text { perceptions, self-care } \\
\text { behaviours and their } \\
\text { relationship in } \\
\text { recently diagnosed } \\
\text { type } 2 \text { diabetes } \\
\text { mellitus (T2DM) } \\
\text { patients with and } \\
\text { without diabetes- } \\
\text { related complications. }\end{array}$ & The Netherlands & $\begin{array}{l}\mathrm{N}=192 \\
\text { Age: } \mathrm{M}=64.3 \\
\text { Gender: } 55.7 \% \text { male } \\
\text { Education: } 29 \% \text { low, } \\
47.9 \% \text { middle, } 23.2 \% \\
\text { high } \\
\text { Occupation: not } \\
\text { reported } \\
\text { Ethnicity: not } \\
\text { reported } \\
\text { Marital status: } \\
75.3 \% \text { married or } \\
\text { cohabiting } \\
\text { Diabetes duration: }\end{array}$ & Cross-sectional study & $\begin{array}{l}\text { Illness perception } \\
\text { questionnaire-revised } \\
\text { (IPQ-R) }\end{array}$ & $\begin{array}{l}\text { Identity: Low } \\
\text { perception of identity } \\
(\mathrm{M}=0.63) \text {. } \\
\text { Consequences: Not } \\
\text { serious consequences } \\
(\mathrm{M}=2.49) \text {. } \\
\text { Timeline: High } \\
\text { perception of } \\
\text { chronicity }(\mathrm{M}=3.84) \text {. } \\
\text { Cause: } \text { Bad luck } \\
\text { (M=2.66), own } \\
\text { behaviour }(\mathrm{M}=2.49) \\
\text { or psychological } \\
\text { factors (M=2.20). } \\
\text { Control: } \text { Through } \\
\text { own behaviour }\end{array}$ \\
\hline
\end{tabular}




\begin{tabular}{|c|c|c|c|c|c|c|}
\hline Author and year & $\begin{array}{l}\text { Study aim(s) as } \\
\text { relevant to } \\
\text { current review }\end{array}$ & Country & $\begin{array}{l}\text { Participants } \\
\text { (number } \\
\text { characteristics) }\end{array}$ & Design & Measure(s) & Results \\
\hline & & & mean $=2.3$ years & & & $\begin{array}{l}(\mathrm{M}=2.79) \text { or medical } \\
\text { treatment }(\mathrm{M}=3.78) \text {. } \\
\text { Emotional } \\
\text { representation: } \text { Low } \\
(\mathrm{M}=2.17) \text {. } \\
\text { Illness coherence: } \\
\text { Good }(\mathrm{M}=3.42) \text {. }\end{array}$ \\
\hline $\begin{array}{l}\text { White, Smith, Hevey } \\
\text { \& O’Dowd (2009) }\end{array}$ & $\begin{array}{l}\text { To examine the } \\
\text { relationship between } \\
\text { psychological and } \\
\text { social factors and } \\
\text { diabetes outcomes in } \\
\text { people with type } 2 \\
\text { diabetes and their } \\
\text { family members. }\end{array}$ & Ireland & $\begin{array}{l}\mathrm{N}=153 \\
\text { Age: } \mathrm{M}=59.1 \\
\text { Gender: } 56.2 \% \text { male } \\
\text { Education: } 2.7 \% \text { no } \\
\text { formal; } 38.7 \% \\
\text { primary; } 16 \% \text { junior } \\
\text { certificate, } 24 \% \\
\text { leaving certificate, } \\
\text { 16\% undergraduate, } \\
2.7 \% \text { postgraduate } \\
\text { Occupation: } 21.6 \% \text { I } \\
\text { and II socioeconomic } \\
\text { status, } 25.5 \% \text { III and } \\
\text { IV, } 10.5 \% \text { V and VI, } \\
\text { 26.8\% housewife, } \\
\text { 10.5\% retired, 5.2\% } \\
\text { unemployed } \\
\text { Ethnicity: not } \\
\text { reported } \\
\text { Marital status:: } \\
71.2 \% \text { married, } 12.4 \% \\
\text { single, } 11.1 \% \\
\text { widowed, } 5.2 \% \\
\text { separated } \\
\text { Diabetes duration: }\end{array}$ & Cross-sectional study & $\begin{array}{l}\text { Diabetes knowledge } \\
\text { questionnaire (DKQ) } \\
\text { Social support } \\
\text { questionnaire-6 } \\
\text { (SSQ6) } \\
\text { The 12-item well- } \\
\text { being questionnaire } \\
\text { (W-BQ12) } \\
\text { Illness perception } \\
\text { questionnaire (IPQ-R) }\end{array}$ & $\begin{array}{l}\text { Consequences: } \\
\text { Relatives perceived } \\
\text { the consequences of } \\
\text { T2D to be more } \\
\text { serious than patients. } \\
\text { Timeline: Relatives } \\
\text { perceived T2D as } \\
\text { cyclical more than } \\
\text { patients did. } \\
\text { Cause: Diet (71.1\%), } \\
\text { heredity (52.3\%), } \\
\text { aging (50.4\% and } \\
48.5 \% \text { ), own } \\
\text { behaviour ( } 49 \% \\
\text { patients). } \\
\text { Control: Patients } \\
\text { perceived T2D to be } \\
\text { more personally } \\
\text { controllable than } \\
\text { relatives did. } \\
\text { Emotional } \\
\text { representation: No } \\
\text { difference in } \\
\text { emotional distress } \\
\text { between patients and } \\
\text { relatives. }\end{array}$ \\
\hline
\end{tabular}


Journal Name, 2014, Vol. O, No. 019

\begin{tabular}{|c|c|c|c|c|c|c|}
\hline Author and year & $\begin{array}{l}\text { Study aim(s) as } \\
\text { relevant to } \\
\text { current review }\end{array}$ & Country & $\begin{array}{l}\text { Participants } \\
\text { (number } \\
\text { characteristics) }\end{array}$ & Design & Measure(s) & Results \\
\hline & & & not reported & & & $\begin{array}{l}\text { Illness coherence: } \\
\text { Relatives perceive the } \\
\text { have significantly less } \\
\text { understanding about } \\
\text { T2D than patients. }\end{array}$ \\
\hline $\begin{array}{l}\text { Woolthuis, de Grauw, } \\
\text { Cardol, van Weel, } \\
\text { Metsemakers \& } \\
\text { Bierman (2013) }\end{array}$ & $\begin{array}{l}\text { To investigate how } \\
\text { the route to diagnosis } \\
\text { of type } 2 \text { diabetes } \\
\text { (through screening } \\
\text { versus clinical } \\
\text { symptoms) affects } \\
\text { illness perceptions of } \\
\text { patients and their } \\
\text { partners. }\end{array}$ & The Netherlands & $\begin{array}{l}\mathrm{N}=109 \text { patients } \\
\text { Age: } 60.3 \\
\text { Gender: } 42 \text { male and } \\
22 \text { male } \\
\text { Education: primary } 8 \\
\text { and } 10 ; \text { secondary } 59 \\
\text { and } 14 \text {; tertiary } 8 \text { and } \\
8 \\
\text { Occupation: } \\
\text { employed } 24 \text { and } 9 ; \\
\text { homemaker } 13 \text { and } 6 \text {; } \\
\text { unemployed } 9 \text { and } 5 \text {, } \\
\text { retired } 30 \text { and } 11 \\
\text { Ethnicity: not } \\
\text { reported } \\
\text { Marital status: not } \\
\text { reported } \\
\text { Diabetes duration: } \\
23 \text { under } 6 \text { months }\end{array}$ & Cross-sectional & $\begin{array}{l}\text { The brief illness } \\
\text { perception } \\
\text { questionnaire (Brief } \\
\text { IPQ) } \\
\text { The revised illness } \\
\text { perception } \\
\text { questionnaire (IPQ-R) }\end{array}$ & $\begin{array}{l}\text { Identity: Symptoms } \\
\text { experienced by } \\
\text { patient (M=3.55). } \\
\text { Consequences: High } \\
\text { perception }(\mathrm{M}=4.2) \text {. } \\
\text { Timeline: High } \\
\text { perception of } \\
\text { chronicity (M=7.8) } \\
\text { Cause: } \text { Screening } \\
\text { detected patients were } \\
\text { less likely to identify } \\
\text { lifestyle as the cause } \\
\text { and more likely to } \\
\text { believe that heredity } \\
\text { plays a causal role. } \\
\text { Control: } \text { Moderate } \\
\text { (M=6.4) } \\
\text { Emotional } \\
\text { representation: Low } \\
\text { (M=3.4) } \\
\text { Illness coherence: } \\
\text { High (M=7.2) }\end{array}$ \\
\hline
\end{tabular}


Table 3 Summary of Included Qualitative studies

\begin{tabular}{|c|c|c|c|c|c|}
\hline Author and year & $\begin{array}{l}\text { Study aim(s) as relevant } \\
\text { to the current review }\end{array}$ & Country & $\begin{array}{l}\text { Participants (number and } \\
\text { characteristics) }\end{array}$ & Design/Methodology & Findings \\
\hline Alcozer (2000) & $\begin{array}{l}\text { To investigate the } \\
\text { explanatory models of } \\
\text { diabetes from the } \\
\text { perspective of Mexican } \\
\text { American women with } \\
\text { type } 2 \text { diabetes? }\end{array}$ & USA & $\begin{array}{l}\mathrm{N}=20 \text { Mexican Americans } \\
\text { Age: } \mathrm{M}=33 \\
\text { Gender: } 100 \% \text { female } \\
\text { Education: } 10 \%<12^{\text {th }} \\
\text { grade, } 60 \% \text { high school, } \\
20 \% \text { college/tech school, } \\
10 \% \text { college graduate } \\
\text { Occupation: not reported } \\
\text { Ethnicity: not reported } \\
\text { Marital status: } 18 \\
\text { partnered, } 2 \text { married } \\
\text { Diabetes duration: } \mathrm{M}=6 \\
\text { years }\end{array}$ & $\begin{array}{l}\text { Exploratory qualitative study, } \\
\text { open-ended interviews, } \\
\text { observations, thematic and } \\
\text { pattern analysis }\end{array}$ & $\begin{array}{l}\text { Five thematic categories: } \\
\text { Defining diabetes: } \\
\text { borderline or glucose } \\
\text { intolerant meant "sugar in } \\
\text { my urine" and it "wasn't } \\
\text { so bad". Diabetes meant } \\
\text { "sugar in my blood" and } \\
\text { was described as "scary } \\
\text { because of all the damage" } \\
\text { Getting diabetes): heredity } \\
\text { and eating too many } \\
\text { sweets were identified as } \\
\text { the main causes of diabetes } \\
\text { Having diabetes: described } \\
\text { as having high sugar and } \\
\text { as a confusing illness } \\
\text { Describing diabetes: the } \\
\text { description was linked to } \\
\text { the definition of the illness } \\
\text { (borderline or diabetes) } \\
\text { Insulin was regarded as a } \\
\text { consequence and a } \\
\text { symptom: needing insulin } \\
\text { is a symptom of diabetes } \\
\text { and insulin causes } \\
\text { complications } \\
\text { Taking care of diabetes: } \\
\text { Treatment was viewed as } \\
\text { congruent with knowledge } \\
\text { of symptoms. }\end{array}$ \\
\hline $\begin{array}{l}\text { Al-Qazaz, Hassali, Shafie, } \\
\text { Sulaiman \& Sundram, }\end{array}$ & $\begin{array}{l}\text { To explore type } 2 \text { diabetes } \\
\text { patients' experience and }\end{array}$ & Malaysia & $\mathrm{N}=12$ & $\begin{array}{l}\text { Exploratory qualitative study, } \\
\text { semi-structured interviews, }\end{array}$ & $\begin{array}{l}\text { Only a few of the } \\
\text { participants knew if they } \\
\text { have type } 1 \text { or type } 2\end{array}$ \\
\hline
\end{tabular}


Journal Name, 2014, Vol. 0, No. 021

\begin{tabular}{|c|c|c|c|c|c|}
\hline Author and year & $\begin{array}{l}\text { Study aim(s) as relevant } \\
\text { to the current review }\end{array}$ & Country & $\begin{array}{l}\text { Participants (number and } \\
\text { characteristics) }\end{array}$ & Design/Methodology & Findings \\
\hline 2011 & knowledge about diabetes & & $\begin{array}{l}\text { Age: range } 45 \text { to over } 63 \\
\text { Gender: } 8 \text { male, } 4 \text { female } \\
\text { Education: } 2 \text { primary, } 8 \\
\text { secondary, } 2 \text { university } \\
\text { Occupation: not reported } \\
\text { Ethnicity: not reported } \\
\text { Marital status: not } \\
\text { reported } \\
\text { Diabetes duration: range: } \\
1 \text { to more than } 6 \text { years }\end{array}$ & thematic content analysis & $\begin{array}{l}\text { diabetes. } \\
\text { All of them knew the name } \\
\text { of the drugs used for } \\
\text { treatment. } \\
\text { Genetic factors were the } \\
\text { main cause identified, } \\
\text { followed by dietary habits } \\
\text { and lack of exercise. }\end{array}$ \\
\hline $\begin{array}{l}\text { Baggio, Santos, Sales \& } \\
\text { Marcon (2013) }\end{array}$ & $\begin{array}{l}\text { To identify how people } \\
\text { suffering from type } 2 \\
\text { diabetes, re-hospitalised } \\
\text { due to uncontrolled } \\
\text { glucose, perceived the } \\
\text { disease, and the reasons } \\
\text { that led to hospitalization. }\end{array}$ & Brazil & $\begin{array}{l}\text { N=7 } \\
\text { Age: males: } 47 \text { to } 71 \text {; } \\
\text { females: } 18 \text { to } 36 . \\
\text { Gender: } 4 \text { males, } 3 \\
\text { females } \\
\text { Education: } 2 \text { illiterate, } 5 \\
\text { had four to eleven years of } \\
\text { schooling } \\
\text { Occupation: } 3 \text { retired, } 2 \\
\text { unemployed, } 1 \text { babysitter, } 1 \\
\text { tractor driver } \\
\text { Ethnicity: not reported } \\
\text { Marital status: not } \\
\text { reported } \\
\text { Diabetes duration: } 2-21 \\
\text { years }\end{array}$ & $\begin{array}{l}\text { Descriptive qualitative study, } \\
\text { semi-structured interviews, } \\
\text { thematic analysis }\end{array}$ & $\begin{array}{l}\text { Participants had a very } \\
\text { negative conception of } \\
\text { type } 2 \text { diabetes. } \\
\text { They identified heredity } \\
\text { and lifestyle as primary } \\
\text { causes. } \\
\text { They also recognised the } \\
\text { complications resulting } \\
\text { from type } 2 \text { diabetes }\end{array}$ \\
\hline Chun \& Chesla (2004) & $\begin{array}{l}\text { To explore Chinese } \\
\text { patients' and their spouses' } \\
\text { perceptions of type } 2\end{array}$ & USA & $\begin{array}{l}\mathrm{N}=20 \\
\text { Age: } \mathrm{M}=60.85 \text { years } \\
\text { Gender: patients: } 9 \text { men, } 4\end{array}$ & $\begin{array}{l}\text { Exploratory qualitative study, } \\
\text { group interviews (patients only } \\
\text { or spouses only), interpretive }\end{array}$ & $\begin{array}{l}\text { Five themes: } \\
\text { Conceptualisation of } \\
\text { Diabetes, Illness and }\end{array}$ \\
\hline
\end{tabular}




\begin{tabular}{|c|c|c|c|c|c|}
\hline Author and year & $\begin{array}{l}\text { Study aim(s) as relevant } \\
\text { to the current review }\end{array}$ & Country & $\begin{array}{l}\text { Participants (number and } \\
\text { characteristics) }\end{array}$ & Design/Methodology & Findings \\
\hline & diabetes & & $\begin{array}{l}\text { women } \\
\text { Education: } \mathrm{M}=13.31 \\
\text { years } \\
\text { Occupation: not reported } \\
\text { Ethnicity: not reported } \\
\text { Marital status: years of } \\
\text { marriage } M=29.54 \\
\text { Diabetes duration: } \mathrm{M}= \\
6.54 \text { years }\end{array}$ & phenomenology & $\begin{array}{l}\text { Health: the concept of a } \\
\text { "hot" and } \\
\text { "cold" dynamic related to } \\
\text { the regulation of body } \\
\text { temperature; high blood } \\
\text { glucose produces } \\
\text { "hotness" } \\
\text { Perceived predictors of } \\
\text { diabetes: heredity, a } \\
\text { general decline in health, } \\
\text { undisciplined eating habits, } \\
\text { stress, lack of willpower } \\
\text { and self-discipline. } \\
\text { People with diabetes may } \\
\text { experience shame and } \\
\text { guilt. } \\
\text { Significance and meaning } \\
\text { of food: certain foods can } \\
\text { lower blood glucose levels } \\
\text { Perceptions of Chinese } \\
\text { and Western Medicines: } \\
\text { certain Chinese herbs can } \\
\text { cure the underlying causes } \\
\text { of illness; Western } \\
\text { medicine ameliorates the } \\
\text { symptoms } \\
\text { Exercise and physical } \\
\text { activity: light to moderate } \\
\text { activity is beneficial } \\
\text { Effects of the disease on } \\
\text { family dynamics: } \\
\text { reluctance to show signs us } \\
\text { distress not to upset } \\
\text { family; diabetes alters the } \\
\text { patients' "personality", } \\
\text { making them more prone } \\
\text { to mood swings. }\end{array}$ \\
\hline
\end{tabular}


Journal Name, 2014, Vol. 0, No. 023

\begin{tabular}{|c|c|c|c|c|c|}
\hline Author and year & $\begin{array}{l}\text { Study aim(s) as relevant } \\
\text { to the current review }\end{array}$ & Country & $\begin{array}{l}\text { Participants (number and } \\
\text { characteristics) }\end{array}$ & Design/Methodology & Findings \\
\hline Dietrich (1996) & $\begin{array}{l}\text { To investigate attitudes of } \\
\text { people with diabetes } \\
\text { toward their disease and its } \\
\text { treatment }\end{array}$ & USA & $\begin{array}{l}\mathrm{N}=7 \\
\text { Age: range: } 37-81 \text { years } \\
\text { Gender: } 100 \% \text { female } \\
\text { Education: } 19^{\text {th }} \text { grade, } 1 \\
10^{\text {th }} \text { grade, } 4 \text { high school, } 1 \\
\text { vocational school } \\
\text { Occupation: not reported } \\
\text { Ethnicity: not reported } \\
\text { Marital status: not } \\
\text { reported } \\
\text { Diabetes duration: range: } \\
5 \text { weeks - } 40 \text { years }\end{array}$ & $\begin{array}{l}\text { Exploratory qualitative study, } \\
\text { general interview guide } \\
\text { approach, open ended } \\
\text { interviews, naturalistic content } \\
\text { analysis }\end{array}$ & $\begin{array}{l}\text { Negative feelings at the } \\
\text { time of diagnosis (shock, } \\
\text { panic, fear) and denial. } \\
\text { Participants were afraid of } \\
\text { diabetes. } \\
\text { Feelings of inferiority and } \\
\text { loss of control over one's } \\
\text { life. } \\
\text { Borderline diabetes was } \\
\text { not taken seriously. } \\
\text { "Not feeling sick means } \\
\text { not being sick" }\end{array}$ \\
\hline $\begin{array}{l}\text { Egede \& Bonadonna } \\
(2003)\end{array}$ & $\begin{array}{l}\text { To explore what diabetes } \\
\text { means to African } \\
\text { Americans and the role of } \\
\text { fatalism in self- } \\
\text { management }\end{array}$ & USA & $\begin{array}{l}\text { N=39 } \\
\text { Age: } M=48 \text { years } \\
\text { Gender: } 22 \text { men, } 17 \\
\text { women } \\
\text { Education: not reported } \\
\text { Occupation: not reported } \\
\text { Ethnicity: not reported } \\
\text { Marital status: not } \\
\text { reported } \\
\text { Diabetes duration: } M=13 \\
\text { years }\end{array}$ & $\begin{array}{l}\text { Qualitative exploratory, Gender- } \\
\text { specific focus groups, ISAS } \\
\text { paradigm }\end{array}$ & $\begin{array}{l}\text { Meaning of diabetes: as a } \\
\text { death sentence; as an } \\
\text { inherited disease they have } \\
\text { no control over; } \\
\text { uncontrollable; } \\
\text { generational curse and the } \\
\text { only way to get rid of this } \\
\text { curse is to deny the } \\
\text { existence of the disease; } \\
\text { loss of normalcy and } \\
\text { suffering. } \\
\text { Illness experience: } \\
\text { individuals with long- } \\
\text { standing disease, friends or } \\
\text { relatives with diabetes, } \\
\text { disability from diabetes or } \\
\text { poor social support } \\
\text { appeared to be more } \\
\text { fatalistic. } \\
\text { Coping response: regret } \\
\text { for not being informed } \\
\text { earlier of lifestyle changes }\end{array}$ \\
\hline
\end{tabular}




\begin{tabular}{|c|c|c|c|c|c|}
\hline Author and year & $\begin{array}{l}\text { Study aim(s) as relevant } \\
\text { to the current review }\end{array}$ & Country & $\begin{array}{l}\text { Participants (number and } \\
\text { characteristics) }\end{array}$ & Design/Methodology & Findings \\
\hline & & & & & $\begin{array}{l}\text { that may have helped avoid } \\
\text { diabetes; focused on } \\
\text { preventing their children } \\
\text { and relatives from } \\
\text { developing diabetes } \\
\text { Religious or spiritual } \\
\text { beliefs: having diabetes as } \\
\text { predestined and having } \\
\text { complications is } \\
\text { independent of one's } \\
\text { personal efforts. }\end{array}$ \\
\hline Everett (2011) & $\begin{array}{l}\text { To explore patients' } \\
\text { perceptions of T2D among } \\
\text { people in Oaxaca, Mexico. }\end{array}$ & Mexico & $\begin{array}{l}\text { N=18 } \\
\text { Age: } 24-67 \text { years } \\
\text { Gender: } 4 \text { men, } 14 \text { women } \\
\text { Education: not reported } \\
\text { Occupation: not reported } \\
\text { Marital status: not } \\
\text { reported } \\
\text { Diabetes duration: not } \\
\text { reported }\end{array}$ & $\begin{array}{l}\text { Exploratory qualitative study, } \\
\text { interviews, open-ended } \\
\text { questions }\end{array}$ & $\begin{array}{l}\text { Although some } \\
\text { participants mentioned } \\
\text { diet, lifestyle, obesity and } \\
\text { family history as risk } \\
\text { factors for diabetes, the } \\
\text { majority placed emphasis } \\
\text { on strong emotions (anger, } \\
\text { fear) and traumatic events } \\
\text { as the main causes of type } \\
2 \text { diabetes. } \\
\text { Patients had no concerns } \\
\text { about privacy or stigma } \\
\text { associated with diabetes. }\end{array}$ \\
\hline $\begin{array}{l}\text { Finucane \& McMullen } \\
\text { (2008) }\end{array}$ & $\begin{array}{l}\text { To identify the cultural } \\
\text { values, traditions, and } \\
\text { perceptions of diabetes risk } \\
\text { and self-care among } \\
\text { Filipino Americans in } \\
\text { Hawaii with type } 2 \\
\text { diabetes }\end{array}$ & USA & $\begin{array}{l}\mathrm{N}=15 \\
\text { Age: mean=50.7 } \\
\text { Gender: } 12 \text { female } \\
\text { Education: } 1 \text { completed } 8^{\text {th }} \\
\text { grade, } 2 \text { high school, } 5 \\
\text { college or two-year degree, } \\
7 \text { four-year college degree, } \\
1 \text { more than four-year } \\
\text { degree } \\
\text { Occupation: not reported } \\
\text { Marital status: not } \\
\text { reported }\end{array}$ & $\begin{array}{l}\text { Exploratory qualitative, two } \\
\text { rounds of focus groups (same } \\
\text { participants), qualitative theme } \\
\text { analysis }\end{array}$ & $\begin{array}{l}\text { Participants reported } \\
\text { feelings of shame, } \\
\text { humiliation and guilt about } \\
\text { having diabetes. } \\
\text { Some people believed that } \\
\text { they deserve diabetes } \\
\text { because they have done } \\
\text { something bad. They } \\
\text { viewed diabetes as } \\
\text { punishment. } \\
\text { Participants were aware of } \\
\text { the diabetes risk factors } \\
\text { such as family history, }\end{array}$ \\
\hline
\end{tabular}


Journal Name, 2014, Vol. 0, No. 025

\begin{tabular}{|c|c|c|c|c|c|}
\hline Author and year & $\begin{array}{l}\text { Study aim(s) as relevant } \\
\text { to the current review }\end{array}$ & Country & $\begin{array}{l}\text { Participants (number and } \\
\text { characteristics) }\end{array}$ & Design/Methodology & Findings \\
\hline & & & $\begin{array}{l}\text { Diabetes duration: range } \\
\text { from less than a year to } \\
\text { over } 5 \text { years }\end{array}$ & & $\begin{array}{l}\text { diet, physical activity. } \\
\text { They had limited } \\
\text { understanding of the } \\
\text { problems diabetes can } \\
\text { cause to major organs. } \\
\text { Most patients did not } \\
\text { associate diabetes with } \\
\text { feelings of dread but they } \\
\text { associated with negative } \\
\text { emotions. }\end{array}$ \\
\hline $\begin{array}{l}\text { Habte, Kebede, Fenta \& } \\
\text { Boon (2016) }\end{array}$ & $\begin{array}{l}\text { To explore the illness } \\
\text { perceptions of type } 2 \\
\text { diabetes patients attending } \\
\text { treatment in Addis Ababa } \\
\text { and Butajira } \\
\text { (Ethiopia) }\end{array}$ & Ethiopia & $\begin{array}{l}\text { N=39 } \\
\text { Age: } 2 \text { between } 30-39,8 \\
\text { between } 40-49,14 \text { between } \\
50-59,10 \text { between } 60-69 \text {, } \\
5>70 \\
\text { Gender: } 19 \text { female, } 20 \\
\text { male } \\
\text { Education: } 6 \text { illiterate, } 10 \\
\text { basic literacy, } 8 \text { elementary } \\
\text { school, } 8 \text { secondary school } \\
\text { complete, } 7 \text { post-secondary } \\
\text { Occupation: } 7 \text { clerical } \\
\text { work, } 4 \text { rents house, } 5 \\
\text { small business, } 5 \text { farming, } \\
9 \text { pensioner, } 5 \text { unemployed, } \\
4 \text { others } \\
\text { Marital status: } 27 \\
\text { married, } 8 \text { widowed, } 4 \\
\text { divorced/single } \\
\text { Diabetes duration (years): } \\
10 \text { between } 1-5 \text { years, } 14 \\
\text { between 6-10 years, } 7 \\
\text { between } 11-15 \text { years, } 4 \\
\text { between } 16-20 \text { years, } 4 \\
\text { between } 21-25 \text { years }\end{array}$ & Individual in-depth interviews & $\begin{array}{l}\text { Labelling diabetes: } \\
\text { described as "sugar } \\
\text { disease", disease of the } \\
\text { rich who indulge in diet } \\
\text { and who are rich enough to } \\
\text { afford to manage it. } \\
\text { Emotions: startled, } \\
\text { hopeless, upset } \\
\text { Symptoms: Thirst, frequent } \\
\text { urination, weakness, } \\
\text { weight loss; did not link } \\
\text { symptoms with diabetes } \\
\text { Chronicity: Many thought } \\
\text { it is an acute illness, which } \\
\text { will be cured. Others } \\
\text { though it is a deadly } \\
\text { disease that will kill them } \\
\text { in a short period of time. } \\
\text { Impact of diabetes: } \\
\text { Consequences are } \\
\text { perceived to be low but } \\
\text { increased with diabetes } \\
\text { duration. They ranged } \\
\text { included physical (liver, } \\
\text { kidney, eyesight problems, } \\
\text { limb amputation) and } \\
\text { social (affects relationships }\end{array}$ \\
\hline
\end{tabular}




\begin{tabular}{|c|c|c|c|c|c|}
\hline Author and year & $\begin{array}{l}\text { Study aim(s) as relevant } \\
\text { to the current review }\end{array}$ & Country & $\begin{array}{l}\text { Participants (number and } \\
\text { characteristics) }\end{array}$ & Design/Methodology & Findings \\
\hline & & & & & $\begin{array}{l}\text { because type } 2 \text { diabetes } \\
\text { makes people short- } \\
\text { tempered). } \\
\text { Cause: Heredity, emotions } \\
\text { (anger, rage, grief), } \\
\text { lifestyle, evil spirits } \\
\text { Treatment: Easily } \\
\text { controlled through } \\
\text { biomedical treatment, } \\
\text { religious healing and } \\
\text { traditional medicines. }\end{array}$ \\
\hline $\begin{array}{l}\text { Hernandez, Antone \& } \\
\text { Cornelius (1999) }\end{array}$ & $\begin{array}{l}\text { To determine how First } \\
\text { Nations clients with T2D } \\
\text { perceive and live with their } \\
\text { diabetes }\end{array}$ & Canada & $\begin{array}{l}\mathrm{N}=10 \\
\text { Age: } 32 \text { to } 75 \text { years } \\
\text { Gender: } 6 \text { females, } 4 \\
\text { males } \\
\text { Occupation: not reported } \\
\text { Marital status: } 6 \text { married, } \\
1 \text { widowed, } 1 \text { separated, } 1 \\
\text { divorced, } 1 \text { living common- } \\
\text { law } \\
\text { Diabetes duration: } 2 \text { to } 32 \\
\text { years }\end{array}$ & $\begin{array}{l}\text { Exploratory qualitative, } \\
\text { grounded theory, interviews }\end{array}$ & $\begin{array}{l}\text { Having diabetes: denying } \\
\text { diabetes, minimizing } \\
\text { thoughts and feelings } \\
\text { about diabetes, and } \\
\text { normalizing life so it is the } \\
\text { same as it was before the } \\
\text { diagnosis of T2D. } \\
\text { Concerns about loss of } \\
\text { freedom, mortality and } \\
\text { complications. } \\
\text { Lack of T2D knowledge } \\
\text { but no interest in receiving } \\
\text { information. } \\
\text { Turning point: events that } \\
\text { help people recognise their } \\
\text { diabetes and move past the } \\
\text { denial stage. } \\
\text { Science of one: diabetes is } \\
\text { part of their lives, rooted in } \\
\text { daily habits }\end{array}$ \\
\hline $\begin{array}{l}\text { Hughes, Keith, Byars \& } \\
\text { Wiginton, } 2012\end{array}$ & $\begin{array}{l}\text { To determine the issues } \\
\text { and perceptions of persons } \\
\text { newly diagnosed (within } \\
\text { last } 3 \text { months) with type } 2 \\
\text { diabetes. }\end{array}$ & $\begin{array}{l}\text { USA } \\
\end{array}$ & $\begin{array}{l}\mathrm{N}=16 \\
\text { Age: } \text { mean=48.4 } \\
\text { Gender: } 7 \text { men, } 9 \text { women } \\
\text { Education: } 6 \text { no high }\end{array}$ & $\begin{array}{l}\text { Exploratory qualitative, } \\
\text { interviews, post-it notes, } \\
\text { cognitive mapping }\end{array}$ & $\begin{array}{l}\text { The words most commonly } \\
\text { associated with "living } \\
\text { with diabetes" were: } \\
\text { Eat (diet, food, sweets, } \\
\text { sugar, meal, carbs) }\end{array}$ \\
\hline
\end{tabular}


Journal Name, 2014, Vol. 0, No. 027

\begin{tabular}{|c|c|c|c|c|c|}
\hline Author and year & $\begin{array}{l}\text { Study aim(s) as relevant } \\
\text { to the current review }\end{array}$ & Country & $\begin{array}{l}\text { Participants (number and } \\
\text { characteristics) }\end{array}$ & Design/Methodology & Findings \\
\hline & & & $\begin{array}{l}\text { school, } 10 \text { high school or } \\
\text { college/university degree } \\
\text { Occupation: } 4 \text { full-time, } 1 \\
\text { part-time, } 3 \text { seasonal, } 8 \\
\text { retired or unemployed } \\
\text { Marital status: } 11 \\
\text { married, } 1 \text { separated, } 3 \\
\text { single, } 1 \text { cohabitating } \\
\text { Diabetes duration: } \mathrm{M}=2.6 \\
\text { weeks }\end{array}$ & & $\begin{array}{l}\text { Diabetes (complications, } \\
\text { sick, amputation, death) } \\
\text { Negative emotions (scared, } \\
\text { worried, lonely, anger, } \\
\text { fear, sad, stress, terrible) }\end{array}$ \\
\hline Jayne \& Rankin, 2001 & $\begin{array}{l}\text { To demonstrate the } \\
\text { application of Leventhal's } \\
\text { Self-regulation model with } \\
\text { a group of Chinese } \\
\text { immigrants with T2D }\end{array}$ & USA & $\begin{array}{l}\mathrm{N}=30 \\
\text { Age: range } 46-80 \text { years } \\
\text { Gender: } 17(57 \%) \text { men } \\
\text { Education: } 18(62 \%) \text { less } \\
\text { than high-school; } 5(17 \%) \\
\text { college; } \\
\text { Occupation: } 7 \\
\text { homemakers, } 7 \text { employed, } \\
10 \text { retired. } \\
\text { Marital status: } 23 \text { ( } 77 \%) \\
\text { married } \\
\text { Diabetes duration: } 19 \text { had } \\
\text { been aware of it for } 10 \\
\text { years or less }\end{array}$ & $\begin{array}{l}\text { Non-experimental, exploratory, } \\
\text { qualitative, interviews: the } \\
\text { questions addressed each of the } \\
\text { components of the SR model }\end{array}$ & $\begin{array}{l}\text { Cause of T2D } \\
23 \text { (74\%) indicated eating } \\
\text { behaviour as a cause of } \\
\text { T2D. } 10 \text { related T2D to } \\
\text { heredity. } 30 \% \text { mentioned } \\
\text { stress and depressing.7 did } \\
\text { not know/. 100\% blamed } \\
\text { themselves for developing } \\
\text { T2D. } \\
\text { Identity } \\
\text { Some of the participants } \\
\text { experienced symptoms of } \\
\text { increased thirst, fatigue, } \\
\text { weight loss, frequent } \\
\text { urination or blurred vision } \\
\text { while other had no } \\
\text { symptoms. } \\
\text { Perception of severity was } \\
\text { related to acuteness of } \\
\text { symptoms and the } \\
\text { presence of complications. } \\
\text { Without symptoms the } \\
\text { diagnosis came as a } \\
\text { surprise. T2D resulted in } \\
\text { being labelled as different } \\
\text { and T2D is described as a }\end{array}$ \\
\hline
\end{tabular}




\begin{tabular}{|c|c|c|c|c|c|}
\hline Author and year & $\begin{array}{l}\text { Study aim(s) as relevant } \\
\text { to the current review }\end{array}$ & Country & $\begin{array}{l}\text { Participants (number and } \\
\text { characteristics) }\end{array}$ & Design/Methodology & Findings \\
\hline & & & & & $\begin{array}{l}\text { social disease } \\
\text { Consequences } \\
77 \% \text { feared becoming } \\
\text { blind or having body limps } \\
\text { amputated. } \\
\text { Timeline } \\
50 \% \text { said t2D is a long } \\
\text { term condition. Some } \\
\text { expected it to be cured. } \\
13 \text { people did not answer } \\
\text { the question. }\end{array}$ \\
\hline Jezewski \& Poss (2002) & $\begin{array}{l}\text { To develop a culturally } \\
\text { specific explanatory model } \\
\text { (EM) of type } 2 \text { diabetes } \\
\text { from the perspective of } \\
\text { Mexican Americans living } \\
\text { along the United States- } \\
\text { Mexican border. }\end{array}$ & Mexico & $\begin{array}{l}\mathrm{N}=22 \\
\text { Age: } \mathbf{M}=53 \\
\text { Gender: } 18 \text { women and } 4 \\
\text { men } \\
\text { Education: average = } 6 \\
\text { years, range: } 0 \text { to } 14 \\
\text { Occupation: not reported } \\
\text { Marital status: not } \\
\text { reported } \\
\text { Diabetes duration: } \\
\text { average =14 years, range: } 1 \\
\text { to } 45 \text { years }\end{array}$ & $\begin{array}{l}\text { Descriptive qualitative, } \\
\text { grounded theory, interviews, } \\
\text { focus groups }\end{array}$ & $\begin{array}{l}\text { Cause: susto (a scare or } \\
\text { fright) or strong anger. } \\
\text { Being overweight, } \\
\text { heredity, lack of exercise, } \\
\text { diet and not taking care of } \\
\text { oneself were also viewed } \\
\text { as contributing to the } \\
\text { development of T2D. } \\
\text { Symptoms: visual } \\
\text { problems, fatigue, } \\
\text { weakness, headaches, dry } \\
\text { mouth, weight loss. } \\
\text { Treatment: traditional } \\
\text { remedies and herbs; } \\
\text { regulation of diet was seen } \\
\text { as important but there was } \\
\text { lack of knowledge and } \\
\text { adherence to diet regimen. } \\
\text { Fear that insulin causes } \\
\text { blindness and leads to } \\
\text { addiction. The importance } \\
\text { of regular exercise was } \\
\text { recognised but there was } \\
\text { variation in how the } \\
\text { interpretation of need for }\end{array}$ \\
\hline
\end{tabular}


Journal Name, 2014, Vol. 0, No. 029

\begin{tabular}{|c|c|c|c|c|c|}
\hline Author and year & $\begin{array}{l}\text { Study aim(s) as relevant } \\
\text { to the current review }\end{array}$ & Country & $\begin{array}{l}\text { Participants (number and } \\
\text { characteristics) }\end{array}$ & Design/Methodology & Findings \\
\hline & & & & & $\begin{array}{l}\text { exercise. } \\
\text { Social significant: only } \\
\text { one participant was } \\
\text { ashamed of her diabetes. } \\
\text { The rest shared the } \\
\text { diagnosis and sought } \\
\text { support from family } \\
\text { members. }\end{array}$ \\
\hline $\begin{array}{l}\text { Lawton, Ahmad, Peel \& } \\
\text { Hallowell, } 2007\end{array}$ & $\begin{array}{l}\text { To explore understanding } \\
\text { of diabetes and its } \\
\text { causation among Pakistani } \\
\text { and Indian and Scottish } \\
\text { T2D patients. }\end{array}$ & Scotland & $\begin{array}{l}\text { Pakistani and Indian } \\
\text { sample N= } 32 \\
\text { Age: mean=59, range } 33- \\
78 \text { years } \\
\text { Gender: } 15 \text { males, } 17 \\
\text { females } \\
\text { Education: not reported } \\
\text { Occupation: not reported } \\
\text { Marital status: not } \\
\text { reported } \\
\text { Diabetes duration: range } \\
\text { 1-30 years } \\
\text { White Scottish sample - } \\
\text { N=32 } \\
\text { Age: mean=56, range } 36- \\
77 \text { years } \\
\text { Gender: } 15 \text { men, } 17 \\
\text { women } \\
\text { Education: not reported } \\
\text { Occupation: not reported } \\
\text { Marital status: not } \\
\text { reported } \\
\text { Diabetes duration: range } \\
1-30 \text { years }\end{array}$ & $\begin{array}{l}\text { Exploratory qualitative, repeat } \\
\text { interview design, grounded } \\
\text { theory }\end{array}$ & $\begin{array}{l}\text { The role of self in the onset } \\
\text { of diabetes: Pakistani and } \\
\text { Indian sample: T2D was } \\
\text { perceived to be caused by } \\
\text { external contextual factors } \\
\text { that the respondents had no } \\
\text { control over. } \\
\text { White sample: the causes } \\
\text { of diabetes were linked to } \\
\text { participants' personal } \\
\text { lifestyle } \\
\text { Attributing blame: } \\
\text { Indian and Pakistani } \\
\text { sample: externalised } \\
\text { responsibility for T2D } \\
\text { development; perceived } \\
\text { the disease to be inevitable } \\
\text { (heredity) or caused by } \\
\text { contextual factors such as } \\
\text { unhealthy lifestyle in } \\
\text { response to the Western } \\
\text { culture (food availability) } \\
\text { and stress associated with } \\
\text { arriving and living in a } \\
\text { foreign country, and with } \\
\text { British medication } \\
\text { White sample: internalised } \\
\text { blame for their T2D; } \\
\text { Associated it with their } \\
\text { personal "unhealthy" }\end{array}$ \\
\hline
\end{tabular}




\begin{tabular}{|c|c|c|c|c|c|}
\hline Author and year & $\begin{array}{l}\text { Study aim(s) as relevant } \\
\text { to the current review }\end{array}$ & Country & $\begin{array}{l}\text { Participants (number and } \\
\text { characteristics) }\end{array}$ & Design/Methodology & Findings \\
\hline & & & & & $\begin{array}{l}\text { lifestyle; perceived } \\
\text { themselves as responsible } \\
\text { for developing T2D; } \\
\text { genetic predisposition did } \\
\text { not suffice as an } \\
\text { explanation. }\end{array}$ \\
\hline Macaden \& Clarke (2006) & $\begin{array}{l}\text { To explore the experiences } \\
\text { of South Asian people with } \\
\text { T2D in the UK }\end{array}$ & UK & $\begin{array}{l}\mathrm{N}=20 \\
\text { DEMOGRAPHICS } \\
\text { Not reported }\end{array}$ & $\begin{array}{l}\text { Exploratory, qualitative, } \\
\text { grounded theory, focus groups }\end{array}$ & $\begin{array}{l}\text { Cause } \\
\text { Cold weather, worrying } \\
\text { too much, having eaten too } \\
\text { many sweets, fate } \\
\text { Severity } \\
\text { Depended on whether or } \\
\text { not they are on insulin, the } \\
\text { number of tablets they take } \\
\text { and the frequency of } \\
\text { hospital visits. } \\
\text { Control } \\
\text { Control was external and } \\
\text { they relied on health care } \\
\text { professionals }\end{array}$ \\
\hline $\begin{array}{l}\text { Murphy \& Kinmonth } \\
\text { (1995) }\end{array}$ & $\begin{array}{l}\text { To explore patients' } \\
\text { understanding of type } 2 \\
\text { diabetes }\end{array}$ & UK & $\begin{array}{l}\mathrm{N}=46 \\
\text { Age: mean=66 years } \\
\text { Gender: } 24 \text { men, } 22 \\
\text { women } \\
\text { Education: not reported } \\
\text { Occupation: } 16 \text { non- } \\
\text { manual, } 30 \text { manual } \\
\text { Marital status: not } \\
\text { reported } \\
\text { Diabetes duration: } \mathrm{M}=8.2\end{array}$ & $\begin{array}{l}\text { Exploratory qualitative, } \\
\text { interviews }\end{array}$ & $\begin{array}{l}\text { Orientation towards } \\
\text { diabetes: } \\
\text { Focusing upon symptoms: } \\
\text { participants discussed } \\
\text { diabetic control in terms of } \\
\text { symptom avoidance; in the } \\
\text { absence of symptoms there } \\
\text { was no risk of } \\
\text { complications, some even } \\
\text { denied they had T2D; they } \\
\text { engaged in temporary } \\
\text { behaviour adjustments in } \\
\text { response to symptoms. } \\
\text { Focusing upon } \\
\text { complications: } \\
\text { These participants }\end{array}$ \\
\hline
\end{tabular}


Journal Name, 2014, Vol. O, No. 031

\begin{tabular}{|c|c|c|c|c|c|}
\hline Author and year & $\begin{array}{l}\text { Study aim(s) as relevant } \\
\text { to the current review }\end{array}$ & Country & $\begin{array}{l}\text { Participants (number and } \\
\text { characteristics) }\end{array}$ & Design/Methodology & Findings \\
\hline & & & & & $\begin{array}{l}\text { prioritised the avoidance of } \\
\text { complication, irrespective } \\
\text { of symptoms. } \\
\begin{array}{l}\text { Perceived seriousness of } \\
\text { diabetes: }\end{array} \\
\text { Serious but not for me: due } \\
\text { to lack of symptoms or } \\
\text { complications, medical } \\
\text { advances and perception of } \\
\text { T2D as a serious in older } \\
\text { people. } \\
\text { Serious but I can control it: } \\
\text { serious effects are } \\
\text { avoidable } \\
\text { Serious for me: pessimistic } \\
\text { about own prognosis }\end{array}$ \\
\hline $\begin{array}{l}\text { Naemiratch \& Manderson } \\
\text { (2006) }\end{array}$ & $\begin{array}{l}\text { To explore lay perceptions } \\
\text { of people with T2D and } \\
\text { their families about } \\
\text { diabetes. }\end{array}$ & Thailand & $\begin{array}{l}\mathrm{N}=33 \\
\text { Age: } \mathrm{M}=54.7 \\
\text { Gender: } 17 \text { men, } 16 \\
\text { women } \\
\text { Education: } 32 \text { basic } \\
\text { education, } 1 \text { without basic } \\
\text { education } \\
\text { Occupation: not reported } \\
\text { Marital status: not } \\
\text { reported } \\
\text { Diabetes duration: not } \\
\text { reported }\end{array}$ & $\begin{array}{l}\text { Ethnographic study, interviews, } \\
\text { conversational methods }\end{array}$ & $\begin{array}{l}\text { The nature of T2D was } \\
\text { described in terms of } \\
\text { visibility and invisibility } \\
\text { but not in terms of } \\
\text { symptoms but in terms of } \\
\text { impact on daily life. An } \\
\text { invisible form of T2D may } \\
\text { have symptoms but they do } \\
\text { not affect daily activities. } \\
\text { These perceptions affected } \\
\text { self-management. } \\
\text { Participants associated } \\
\text { T2D with control but they } \\
\text { were ambivalent whether } \\
\text { they control the disease or } \\
\text { the disease controls them. }\end{array}$ \\
\hline Nguyen (2014) & $\begin{array}{l}\text { To explore illness } \\
\text { representations } \\
\text { (Leventhal's model) of }\end{array}$ & USA & $\begin{array}{l}\mathrm{N}=23 \\
\text { Age: } \mathrm{M}=64.7\end{array}$ & $\begin{array}{l}\text { Descriptive ethnography design, } \\
\text { face-to-face semi-structured } \\
\text { interviews, field notes. }\end{array}$ & $\begin{array}{l}\text { Labelling of diabetes: } \\
\text { T2D was labelled as a } \\
\text { disease with sugar in the }\end{array}$ \\
\hline
\end{tabular}




\begin{tabular}{|c|c|c|c|c|c|}
\hline Author and year & $\begin{array}{l}\text { Study aim(s) as relevant } \\
\text { to the current review }\end{array}$ & Country & $\begin{array}{l}\text { Participants (number and } \\
\text { characteristics) }\end{array}$ & Design/Methodology & Findings \\
\hline & Vietnamese T2D patients & & $\begin{array}{l}\text { Gender: not reported } \\
\text { Education: not reported } \\
\text { Occupation: not reported } \\
\text { Marital status: not } \\
\text { reported } \\
\text { Diabetes duration: not } \\
\text { reported }\end{array}$ & & $\begin{array}{l}\text { urine. If this symptom was } \\
\text { not present, the presence of } \\
\text { T2D was denied. } \\
\text { Symptom-oriented self- } \\
\text { management behaviour. } \\
\text { Perceived causal } \\
\text { mechanism } \\
\text { Diet (eating too much } \\
\text { rice), family history and } \\
\text { stress were identified as } \\
\text { main risk factors. } \\
\text { Perceived consequences } \\
\text { The lack of pain was } \\
\text { associated with low } \\
\text { perceived threat. } \\
\text { Knowledge about the } \\
\text { pathophysiology of } \\
\text { complications was } \\
\text { medically inadequate. T2D } \\
\text { also affected quality of } \\
\text { life. } \\
\text { Timeline trajectory } \\
\text { Curability was used } \\
\text { interchangeably with } \\
\text { diabetes management. } \\
\text { Most of the participants } \\
\text { views T2D as a life-long } \\
\text { condition with an unlikely } \\
\text { cure. } \\
\text { Controllability } \\
\text { Western oral medicines } \\
\text { were perceived as } \\
\text { important for diabetes } \\
\text { control; participants } \\
\text { believed they can feel it if } \\
\text { glucose levels are } \\
\text { abnormal; diet }\end{array}$ \\
\hline
\end{tabular}


Journal Name, 2014, Vol. 0, No. 033

\begin{tabular}{|c|c|c|c|c|c|}
\hline Author and year & $\begin{array}{l}\text { Study aim(s) as relevant } \\
\text { to the current review }\end{array}$ & Country & $\begin{array}{l}\text { Participants (number and } \\
\text { characteristics) }\end{array}$ & Design/Methodology & Findings \\
\hline & & & & & $\begin{array}{l}\text { modification and home } \\
\text { remedies were also } \\
\text { perceived as effective in } \\
\text { controlling diabetes } \\
\text { symptoms. } \\
\text { Adaptive and coping } \\
\text { decisions } \\
\text { Spirituality was seen as a } \\
\text { means to coping and } \\
\text { dealing with } \\
\text { complications. }\end{array}$ \\
\hline $\begin{array}{l}\text { Peel, Parry, Douglas \& } \\
\text { Lawton, } 2004\end{array}$ & $\begin{array}{l}\text { To explore the emotional } \\
\text { reaction of newly } \\
\text { diagnosed patients in } \\
\text { Scotland at the time of } \\
\text { diagnosis }\end{array}$ & Scotland & $\begin{array}{l}\mathrm{N}=40 \\
\text { Age: } \mathrm{M}=48 \\
\text { Gender: } 19 \text { women, } 2 \text { men } \\
\text { Education: not reported } \\
\text { Occupation: } 12 \text { non- } \\
\text { manual class III, } 13 \text { manual } \\
\text { class III , } 5 \text { class IV-V } \\
\text { Marital status: not } \\
\text { reported } \\
\text { Diabetes duration: within } \\
\text { past } 6 \text { months }\end{array}$ & $\begin{array}{l}\text { Exploratory qualitative, in-depth } \\
\text { interviews, thematic analysis }\end{array}$ & $\begin{array}{l}\text { The route to diagnosis } \\
\text { affected emotional } \\
\text { reactions towards T2D: } \\
\text { 1. Suspected diabetes route } \\
\text { to diagnosis: symptoms } \\
\text { => suspected diabetes => } \\
\text { visit to GP and subsequent } \\
\text { diagnosis: many said they } \\
\text { did not experience shock } \\
\text { when diagnosed } \\
\text { Illness route: } \\
\text { Feeling ill => health } \\
\text { service contact and } \\
\text { subsequent diagnosis: } \\
\text { sense of relief; compared } \\
\text { T2D to other illnesses they } \\
\text { might have been diagnosed } \\
\text { with. } \\
\text { Routine route to diagnosis: } \\
\text { absence of symptoms => } \\
\text { routine testing => } \\
\text { diagnosis: for some, T2D } \\
\text { formed a wider pattern of } \\
\text { ill health so it did not } \\
\text { require an emotional } \\
\text { reaction; worry about the }\end{array}$ \\
\hline
\end{tabular}




\begin{tabular}{|c|c|c|c|c|c|}
\hline Author and year & $\begin{array}{l}\text { Study aim(s) as relevant } \\
\text { to the current review }\end{array}$ & Country & $\begin{array}{l}\text { Participants (number and } \\
\text { characteristics) }\end{array}$ & Design/Methodology & Findings \\
\hline & & & & & $\begin{array}{l}\text { interaction between T2D } \\
\text { and other illness they have; } \\
\text { others were glad it was } \\
\text { identified. }\end{array}$ \\
\hline $\begin{array}{l}\text { Péres, Franco \& Santos } \\
\text { (2008) }\end{array}$ & $\begin{array}{l}\text { To explore feelings and } \\
\text { emotional reactions of } \\
\text { women after the diagnosis } \\
\text { of T2D }\end{array}$ & Brazil & $\begin{array}{l}\text { N=8 } \\
\text { Age: range: } 49-76 \text { years } \\
\text { old } \\
\text { Gender: } 100 \% \text { female } \\
\text { Education: } 8 \text { less than } 4^{\text {th }} \\
\text { grade of basic education } \\
\text { Occupation: } 8 \text { housewives } \\
\text { Marital status: not } \\
\text { reported } \\
\text { Diabetes duration: not } \\
\text { reported }\end{array}$ & $\begin{array}{l}\text { Descriptive, exploratory, semi- } \\
\text { structured interviews }\end{array}$ & $\begin{array}{l}\text { Immediately after T2D } \\
\text { diagnosis women felt } \\
\text { anger, rage, sadness, fear, } \\
\text { shock and fright. } \\
\text { They described diabetes as } \\
\text { a disease that doesn't cause } \\
\text { any pain or affect people } \\
\text { much. }\end{array}$ \\
\hline $\begin{array}{l}\text { Pistulka, Winch, Park, Han } \\
\text { \& Kim, } 2012\end{array}$ & $\begin{array}{l}\text { To explore illness } \\
\text { experience of Koreans } \\
\text { with type } 2 \text { diabetes and } \\
\text { hypertension }\end{array}$ & USA & $\begin{array}{l}\mathrm{N}=12 \\
\text { Age: mean=55.9 } \\
\text { Gender: } 8 \text { women, } 4 \text { men } \\
\text { Education: } 12 \text { high school, } \\
5 \text { college } \\
\text { Occupation: not reported } \\
\text { Marital status: not } \\
\text { reported } \\
\text { Diabetes duration: } 8 \text { years }\end{array}$ & $\begin{array}{l}\text { Cross-cultural, qualitative } \\
\text { descriptive inquiry design, } \\
\text { interviews, ethnographic semi- } \\
\text { structured questioning }\end{array}$ & $\begin{array}{l}\text { T2D was perceived as } \\
\text { undermining one's social } \\
\text { image. } \\
\text { Lack of control was } \\
\text { connected with T2D. } \\
\text { People with diabetes were } \\
\text { perceived to have a certain } \\
\text { type of personality and a } \\
\text { character weakness as they } \\
\text { lack discipline. } \\
\text { A public diagnosis may } \\
\text { affect the future of the } \\
\text { offspring as diabetes is } \\
\text { genetic and this may make } \\
\text { children less } \\
\text { "marriageable". } \\
\text { Participants kept their } \\
\text { diagnosis a secret; }\end{array}$ \\
\hline
\end{tabular}


Journal Name, 2014, Vol. 0, No. 035

\begin{tabular}{|c|c|c|c|c|c|}
\hline Author and year & $\begin{array}{l}\text { Study aim(s) as relevant } \\
\text { to the current review }\end{array}$ & Country & $\begin{array}{l}\text { Participants (number and } \\
\text { characteristics) }\end{array}$ & Design/Methodology & Findings \\
\hline & & & & & $\begin{array}{l}\text { revealing the diagnosis } \\
\text { evoked shame, guilt and } \\
\text { regret. }\end{array}$ \\
\hline $\begin{array}{l}\text { White, Smith \& O’Dowd, } \\
2007\end{array}$ & $\begin{array}{l}\text { To explore the beliefs, } \\
\text { attitudes and perceptions } \\
\text { of adults with T2D and } \\
\text { their family members }\end{array}$ & Ireland & $\begin{array}{l}\mathrm{N}=19 \\
\text { Age: median } 68.5 \\
\text { Gender: not reported } \\
\text { Education: not reported } \\
\text { Occupation: not reported } \\
\text { Marital status: not } \\
\text { reported } \\
\text { Diabetes duration: median } \\
\text { 8.5 }\end{array}$ & $\begin{array}{l}\text { Exploratory, qualitative, double- } \\
\text { layer focus group approach, } \\
\text { thematic content analysis }\end{array}$ & $\begin{array}{l}\text { Understanding of T2D } \\
\text { Overall lack of information } \\
\text { and understanding of T2D, } \\
\text { which impacted knowledge } \\
\text { about dietary changes. } \\
\text { Perceptions of T2D } \\
\text { Perceived lack of } \\
\text { knowledge regarding the } \\
\text { cause of T2D; individual } \\
\text { causal attributions (e.g. } \\
\text { disagreement about } \\
\text { balance of sugar, age, } \\
\text { heredity). } \\
\text { Seriousness } \\
\text { Participants, in particular } \\
\text { family members, use } \\
\text { indicators (e.g. number of } \\
\text { hospital appointments, use } \\
\text { of insulin, daily blood } \\
\text { tests) as a marker of } \\
\text { severity. Patients were not } \\
\text { aware of the concerns of } \\
\text { relatives. } \\
\text { Impact on daily life } \\
\text { T2D - always in the back } \\
\text { of the mind; T2D - getting } \\
\text { on with life }\end{array}$ \\
\hline $\begin{array}{l}\text { Yilmaz-Aslan, Brzoska, } \\
\text { Bluhm, Aslan \& Razum, } \\
2014\end{array}$ & $\begin{array}{l}\text { To explore illness } \\
\text { representations among } \\
\text { Turkish migrants with T2D }\end{array}$ & Germany & $\begin{array}{l}\mathrm{N}=24 \\
\text { Age: range } 39-73 \text { years } \\
\text { Gender: } 54 \% \text { female } \\
\text { Education: } 29.1 \% \text { no }\end{array}$ & $\begin{array}{l}\text { Exploratory qualitative, semi- } \\
\text { structured interviews, } \\
\text { constructivism }\end{array}$ & $\begin{array}{l}\text { Timeline } \\
\text { T2D was perceived as } \\
\text { cyclical and permanent. } \\
\text { Patients preferred not to } \\
\text { think about the course of }\end{array}$ \\
\hline
\end{tabular}




\begin{tabular}{|c|c|c|c|c|c|}
\hline Author and year & $\begin{array}{l}\text { Study aim(s) as relevant } \\
\text { to the current review }\end{array}$ & Country & $\begin{array}{l}\text { Participants (number and } \\
\text { characteristics) }\end{array}$ & Design/Methodology & Findings \\
\hline & & & $\begin{array}{l}\text { formal education, } 54.2 \% \\
\text { school education of } 2-5 \\
\text { years, } 16.7 \% 9 \text { or more } \\
\text { years } \\
\text { Occupation: not reported } \\
\text { Marital status: not } \\
\text { reported } \\
\text { Diabetes duration: range } 6 \\
\text { months to } 35 \text { years }\end{array}$ & & $\begin{array}{l}\text { their condition. } \\
\text { Consequences } \\
\text { Physical: worse health } \\
\text { status, body changes } \\
\text { Psychosocial: social } \\
\text { isolation (sometimes } \\
\text { voluntary), loss of } \\
\text { contacts, discrimination, } \\
\text { loss of social functioning } \\
\text { abilities, changes in social } \\
\text { role } \\
\text { Financial } \\
\text { Older men underestimated } \\
\text { the seriousness of T2D } \\
\text { Causal attributions } \\
\text { Low physical activity, diet, } \\
\text { insufficient care for } \\
\text { oneself, aging, heredity, } \\
\text { environment (e.g. poor } \\
\text { working and living } \\
\text { conditions), immigration, } \\
\text { stress, family problems, } \\
\text { fate. } \\
\text { Identity and coherence } \\
\text { T2D was associated with } \\
\text { physical symptoms. } \\
\text { Described as invisible, } \\
\text { non-disturbing due to the } \\
\text { absence of pain. However, } \\
\text { they underlined the } \\
\text { complexity and } \\
\text { unpredictability of T2D } \\
\text { and its impact on daily life. } \\
\text { Control } \\
\text { Through own behaviour by }\end{array}$ \\
\hline
\end{tabular}


Journal Name, 2014, Vol. 0, No. 037

\begin{tabular}{|l|l|l|l|l|}
\hline Author and year & $\begin{array}{l}\text { Study aim(s) as relevant } \\
\text { to the current review }\end{array}$ & Country & $\begin{array}{l}\text { Participants (number and } \\
\text { characteristics) }\end{array}$ & Design/Methodology \\
\hline & & & & Findings \\
& & & $\begin{array}{l}\text { means of physical activity } \\
\text { and diet change; through } \\
\text { powerful others - doctors } \\
\text { and God. T2D was also } \\
\text { described as } \\
\text { uncontrollable. Some } \\
\text { patients exercised control } \\
\text { only when needed (i.e. } \\
\text { when it gets worse) } \\
\text { Emotional representations } \\
\text { Fear of complications }\end{array}$ \\
\hline
\end{tabular}

